\title{
I. HISTORYCZNE KONCEPCJE TEOLOGII
}

(ks. Tadeusz Dzidek, Piotr Sikora)

Kościołowi zawsze towarzyszyła świadomość, że zbudowany jest na prawdzie, w której Bóg objawił ludziom swój zamysł zbawienia. Stąd od zawsze istnieje $\mathrm{w}$ nim pragnienie zrozumienia tej prawdy. Owo rozumowe zgłębianie Objawienia jest rdzeniem chrześcijańskiej teologii. Z czasem precyzowano jej naturę, źródła i metody poznawcze. Obok tego, co na trwałe przyjęto $\mathrm{w}$ teorii teologii, pojawiały się $\mathrm{w}$ trakcie jej uprawiania tendencje, które, w zależności od kontekstu historycznego, akcentowały różne jej wymiary. W tym sensie można mówić o wielu koncepcjach teologii.

Celem niniejszego rozdziału nie jest skrótowa prezentacja historii teologii, ale wydobycie jej zasadniczych koncepcji na przestrzeni prawie dwóch tysiącleci. Tego rodzaju sięgnięcie po doświadczenia teologii z minionych wieków, pozwoli - jak się wydaje - określić podstawowe warunki umożliwiające jej właściwy rozwój.

Naszą prezentację rozpoczniemy od epoki przedchrześcijańskiej. Na tym tle będziemy mogli lepiej dostrzec specyfikę teologii Nowego Testamen$t u$, wywodzącej się ze spotkania ze zmartwychwstałym Jezusem Chrystusem. Teologia ta była miejscem odniesienia dla myśli chrześcijańskiej rozwijanej na przestrzeni wieków. W tej historycznej panoramie wyszczególniamy epokę patrystyczną z jej teologią symboliczną, epokę scholastyczną z rozwijaną teologią dialektyczną oraz epokę nowożytną, w której przeważała teologia historyczna ${ }^{1}$. Prezentację zamyka charakterystyka teologii współczesnej z jej wyraźnym nastawieniem hermeneutycznym.

${ }^{1}$ Por. B. Forte, La teologia come compagnia, memoria e profezia, Milano 1987. Por. także pierwszy rozdział książki: D. KUBICKI, Poszukiwania projektu teologii katolickiej opartej na realizmie stowa objawionego w dziejach, Poznań 2004, s. 41-119. 


\section{A. Epoka przedchrześcijańska - teologia pogańska i żydowska}

Teologia rozumiana jako spontaniczne odkrywanie Objawienia istniała w Kościele zawsze. Niemniej jednak samo słowo „teologia” zostało zastosowane do owego odkrywania o wiele później. Łatwo to wytłumaczyć, jeśli uświadomimy sobie fakt, że słowo to nie występuje ani w Starym, ani w Nowym Testamencie, a w przedchrześcijańskim języku greckim było mocno powiązane z mitologią. Ponadto poddawali je krytyce pogańscy filozofowie starożytności, dla których pierwsi myśliciele chrześcijańscy pochodzenia greckiego mieli wielki szacunek. Jego użycie bez odpowiednich wyjaśnień powodowałoby błędne i niekorzystne skojarzenia, a nawet fałszywe rozumienie natury wiary chrześcijańskiej. Stąd przyjęcie słowa „teologia” dokonywało się powoli i towarzyszyło mu postępujące uściślenie.

Etymologicznie słowo „teologia” pochodzi z języka greckiego i oznacza: słowo, naukę o Bogu. Pierwszym, który używa terminu „teologia” wydaje się być Platon (428-348/7 przed Chr.). W jego Republice ${ }^{2}$ wspomniane pojęcie nie jest używane w sensie doktryny filozoficznej na temat Boga ani tym bardziej w sensie jakiejś teologii Objawienia, lecz jest synonimem „mitologii”. Teologia jest opowiadaniem o bóstwach. Platon poddaje krytyce mity, których autorami są poeci. Stwierdza, że mity odgrywają wielką rolę w wychowaniu młodzieży, jednakże zawierają treści, które mogą być powodem zgorszenia, a nie zbudowania. Dotyczy to postaw bogów naznaczonych moralną słabością. Dlatego postuluje oczyszczenie opowiadań według określonych kryteriów. W takim ujęciu poeci są poprzednikami filozofów, którzy szukają prawdy zawartej w mitach. W podobnym kontekście pojęcia „teologia" używa również Arystoteles (384-322 r. przed Chr.), klasyfikując Hesiodosa (VII/VI w. przed Chr.) i Homera (VIII w. przed Chr.) jako „teologów" - twórców mitów33.

Jednak w Metafizyce Arystotelesa można znaleźć inne fragmenty, w których filozof używa słowa ,teologia” w znaczeniu odmiennym, chociaż odnoszącym się do ujęcia platońskiego, a mianowicie mówi o „teologii filozoficznej" rozumianej jako studium umysłu bazującego na bycie i jego ostatecznych przyczynach ${ }^{4}$. Teologia jest jedną $z$ trzech nauk teoretycznych,

\footnotetext{
${ }^{2}$ Por. Platon, Państwo, II, 3779 a 5, Warszawa 1958.

${ }^{3}$ Por. ARystoteles, Metafizyka, A 938 b 2, Warszawa 1983.

${ }^{4}$ Por. tamże, E 1026 a 19; K 1064 b 3.
} 
obok nauki pierwszej, zajmującej się zasadami bycia i myślenia oraz metafizyki zajmującej się bytem jako takim.

Łącząc ujęcia Platona i Arystotelesa, a także uzupełniając teologię o odniesienia do funkcji społecznej religii i kultu, myśliciele stoiccy: Panaitios z Rodos (185-110 przed Chr.) i Varron (116-27 przed Chr.) doszli do wyodrębnienia trzech typów teologii: 1) teologii mitycznej właściwej legendom poetyckim o bogach; 2) teologii fizycznej (filozoficznej) właściwej filozofom, podejmującej racjonalną refleksję na temat Boga; 3) teologii politycznej (kultycznej) właściwej prawodawcom, którzy zajmują się kultem publicznym popieranym przez miasta-państwa.

Zastosowanie słowa „teologia” przez autorów grecko-rzymskich ujawnia ich ograniczenia w poznaniu Boga, którego osobowość i transcendencja nie zostały w pełni dostrzeżone. Jest to filozofia, która $\mathrm{w}$ zasadzie nie neguje religii, ale suponuje możliwość rozumowego wniknięcia w jej korzenie i aspiruje do takiej roli. Jednakże, nie wznosząc się na poziom jasnej świadomości dotyczącej transcendencji Bożej, jest ciagle narażona na pewną ateistyczną racjonalizację wiedzy religijnej, redukującą Boga żywego, o którym mówią religie, do stanu czysto immanentnego, bezosobowego prawa całego kosmosu.

Paralelne procesy oscylowania pomiędzy pierwotną religijnością powiązaną z mitem, a filozofią chcącą się od niego uwolnić, można zaobserwować w innych religiach: w religii hinduskiej reakcję na mityczność Wed stanowią filozoficzne Upaniszady; oszczędny w swej treści religijnej pierwotny buddyzm zostaje wzbogacony treściami religijnymi i mitycznymi w swych późniejszych formach; z kolei filozofia Tao znajduje swe uzupełnienie $\mathrm{w}$ pragmatyzmie konfucjańskim.

Panorama zmienia się radykalnie $\mathrm{z}$ nadejściem chrześcijaństwa, które pokazało światu grecko-rzymskiemu możliwość zupełnie nowego typu poznania Boga, opartego na słowie, jakie Bóg sam skierował do nas. To właśnie tę wiedzę tradycja chrześcijańska nazywa teologią, nadając $\mathrm{w}$ ten sposób znaczący zwrot semantyczny słowu, które już nie oznacza, jak to miało miejsce w świecie greckim - logosu ludzkiego na temat Boga, lecz raczej uczestnictwo człowieka w Logosie Boskim, to znaczy w poznaniu, które Bóg ma o sobie samym i o całej rzeczywistości ${ }^{5}$.

Słowo „teologia” zadomowiło się w dyskursie chrześcijańskim dopiero w procesie inkulturacji w cywilizację grecką. Tym niemniej równie ważną-

${ }^{5}$ Por. Y. M. Congar, Théologie, [w:] Dictionnaire de Théologie Catholique, t. XV, 342-343; J. L. Illanes, Teologia, [w:] Enciclopedia Rialp (GER), t. XXII, Madrid 1975, s. 232-233; W. KERN, F. J. NIEMANN, Theologische Erkenntnislehre, Leipzig 1983, s. 45-51. 
jeśli nie ważniejszą - poprzedniczką teologii chrześcijańskiej była refleksja religijna rozwijana w Izraelu, zwłaszcza w okresie Drugiej Świątyni ${ }^{6}$.

Teologię judaizmu Drugiej Świątyni cechowało podwójne ukierunkowanie: „prawnicze” i ,historiozbawcze”. Celem refleksji „prawniczej” było określenie sposobu zachowania, który $\mathrm{w}$ danych warunkach historycznych odpowiadałby wymogom Przymierza. Teologia „prawnicza” - halacha - posiadała, mówiąc w uproszczeniu, dwa obszary zastosowania: kult i życie codzienne. Przymierze zostało zawarte w specyficznych warunkach: podczas wędrówki przez pustynię; później zawirowania historyczne zmieniały warunki życia Narodu Wybranego. Zmiana warunków zmuszała do wciąż nowej konkretyzacji wymagań, posiadających swe źródło w doświadczeniu spod Synaju.

Drugim kierunkiem rozwoju teologii międzytestamentalnej - znacznie ważniejszym dla rodzącego się chrześcijaństwa - była refleksja dążąca do zrozumienia religijnego sensu aktualnych wydarzeń historycznych. Wyjątkowe doświadczenie synajskie należało do przeszłości i można było jedynie mieć nadzieję, że kiedyś nastanie czas podobny tamtemu (por. 2 Mch 2, 7 -8). Minęła również, jak sądzono, epoka proroków, którzy dzięki osobistemu, bezpośredniemu doświadczeniu, objawiali aktualne drogi Boże pośród Ludu Wybranego. Aby zrozumieć, jak działa Jahwe w aktualnych wydarzeniach, należało oprzeć się na spisanych dziejach Bożego działania w historii Izraela. Trzeba było je jednak odpowiednio zinterpretować. Służyły temu takie formy refleksji, jak haggada, midrasz czy peszer. Nie wchodząc w ich szczegółową prezentację, można je ogólnie scharakteryzować następująco: Interpretując Pismo, nie koncentrowano się na pierwotnym zamiarze i intencji autora danego tekstu. Stawiano tekstowi pytanie o sens aktualnej sytuacji. Komentarze miały zatem charakter typologiczny - wyszukiwano analogie pomiędzy opisanymi wydarzeniami a aktualną sytuacją. Wyrywano często fragmenty z kontekstu, łączono je na podstawie bardzo różnych, czasami powierzchownych, podobieństw. Wyraźnie zarysowywało się zainteresowanie eschatologią i eschatologicznym znaczeniem tekstu. Prowadziło to do egzegezy alegoryzującej.

Podsumowując można powiedzieć, że teologia judaizmu Drugiej Świątyni była skoncentrowana nie na samodzielnych metafizycznych spekulacjach ani na precyzyjnej egzegezie myśli autorów z przeszłości, lecz na odkryciu Bożych dróg w aktualnych wydarzeniach i rozpoznaniu właściwej ludzkiej odpowiedzi na Boże wymagania. Religijna refleksja międzytesta-

${ }^{6}$ Por. kompetentne opracowanie judaizmu międzytestamentalnego: J. MAIER, Między Starym a Nowym Testamentem, Kraków 2002. 
mentalna dbała o zakorzenienie w tradycji, lecz jednocześnie podporządkowywała pamięć przeszłości zrozumieniu czasu teraźniejszego, a nawet przyszłego. W takim właśnie kontekście powstała najwcześniejsza teologia rodzącego się Kościoła.

\section{B. Nowy Testament - teologia doświadczenia źródłowego}

Ściśle religijny charakter większości przekazu biblijnego budził skojarzenia z religijnymi narracjami innych kultur, w tym także greckiej. Jednakże rozwinięta myśl Starego Testamentu odwoływała się do faktów historycznych: przymierza z Bogiem, Jego wielokrotnych interwencji w dziejach Izraela. To wyraźne odniesienie do historii, w którą wkraczał Stwórca, nadaje księgom starotestamentalnym charakter demitologizujący. Myśl biblijna okazała się wielkim wyzwaniem dla teologii w jej dotychczasowym greckim pojęciu ${ }^{7}$.

Historyczny charakter religii zostaje jeszcze bardziej uwypuklony w Nowym Testamencie, który nie tyle opowiada o Bożych interwencjach w historii za pośrednictwem wydarzeń czy proroków, jak to miało miejsce w Starym Testamencie, ale stwierdza, że Bóg stał się człowiekiem: w określonym czasie urodził się, nauczał, umarł i zmartwychwstał.

Ta bezpośrednia obecność Boga-Człowieka doświadczana przez grono najbliższych mu uczniów, jest źródłem z którego wywodzi się Nowy Testament - zapis pierwszej teologii chrześcijańskiej. Jej autorzy podejmują ogromny wysiłek, by odpowiedzieć na pytania: „kim jest dla nas Jezus?” i „kim jesteśmy my, począwszy od spotkania z Jezusem?”.

\section{Doświadczenie Zmartwychwstałego: anamneza}

Teologia Nowego Testamentu rodzi się w wyniku spotkania, które bywa określane doświadczeniem źródłowym. Inicjuje je, w „trzecim dniu” po ukrzyżowaniu (por. 1 Kor 15, 4), sam Jezus Chrystus. Zmartwychwstały ukazuje się swoim uczniom żywy (Dz 1, 3; 1 Kor 15, 3-8; Łk 24, 34). Wiemy już, że ich relacji nie da się w pełni zharmonizować, z powodu rozbież-

${ }^{7}$ Por. T. WĘCŁAWski, Teologia, [w:] Religia. Encyklopedia PWN, t. 9, Warszawa 2003, s. 249-250. 
ności szczegółów chronologicznych i geograficznych ${ }^{8}$. Ale istnieje w tych relacjach coś, co je jednoczy i pozwala odkryć ich głęboki sens: na początku jest zawsze inicjatywa Zmartwychwstałego. Jego wyjście na spotkanie z uczniami zderza się z oporem, niedowierzaniem. Uczniowie mają trudności, by uwierzyć, że ich Mistrz, umęczony i zabity, rzeczywiście żyje. Ten opór uwidacznia obiektywny charakter spotkania. Dokonuje się ono rzeczywiście, a nie jest wytworem subiektywnych pragnień chwili czy nostalgii za tym, co minęło: Zmartwychwstały przychodzi w sposób obiektywny.

Spotkanie ze Zmartwychwstałym wynika nie tylko z inicjatywy Bożej, ale również z odpowiedzi człowieka. Nie jest ona prostym aktem, przeciwnie - stanowi proces, który zaczyna się od wstępnej wątpliwości, przechodzi przez fazę dojrzewania, przybiera charakter wewnętrznego oświecenia, aż wreszcie kończy się rozpoznaniem Tego, który po śmierci ukazywał się przed nimi jako ktoś, kto przeżywa nowe życie: „Wówczas oczy im się otworzyły i poznali Go" ( $\operatorname{kk} 24,31)^{9}$. To mocne podkreślenie drogi, jaką przebyli uczniowie, by dojść do wyznania wiary, prowadzi nas do odkrycia wymiaru subiektywnego i wewnętrznego spotkania ze Zmartwychwstałym. Przyjście Pana, Jego działanie, nie niszczy ludzkiej wolności. Jest ono ważnym komponentem teologii, jaką zaczną uprawiać świadkowie Jezusa.

U początków teologii odkrywamy Słowo Boga żywego. Odtąd uczniowie odwołują się do spotkania ze Zmartwychwstałym, ono będzie zachowywane $\mathrm{w}$ ich żywej pamięci i głęboko doświadczane w życiu. $\mathrm{W}$ tym sensie teologia nowotestamentalna staje się anamnezą - żywym wspomnieniem oddziałującym na życie jej autorów.

\section{Doświadczenie Ducha Świętego: epikleza}

Spotkanie ze Zmartwychwstałym zostaje dopełnione doświadczeniem zesłania Ducha Świętego. Dzień Pięćdziesiątnicy przemienia uczniów: wewnętrznie umocnieni, już nie zamykają się w swoim kręgu, lecz wychodzą na zewnątrz. Uciekinierzy Wielkiego Piątku przemieniają się $\mathrm{w}$ żywych świadków Paschy. Stają się posłuszni wezwaniu: „Idźcie na cały świat i głoście Ewangelię wszystkim stworzeniom” (Mk 16, 15); „Bóg przywrócił Go do życia, a my jesteśmy tego świadkami” (Dz 3, 15).

${ }^{8}$ Por. T. DZIDEK, Ł. KAMYKOWSKI, A. NAPIÓRKOWSKI (red.), Teologia fundamentalna, t. III, Objawienie i Chrystus, Kraków 1999, s. 142-158.

${ }^{9}$ Cytaty z Pisma Świętego według wydania „Biblii Tysiąclecia”, Poznań ${ }^{3} 1980$, odstępstwa od tej reguły zaznaczono w przypisach. 
Zmartwychwstały obwieścił uczniom nie tylko prawdę o swoim zwycięstwie nad śmiercią i niesprawiedliwością, ale również przekazał im siebie, czyniąc ich w Duchu uczestnikami życia Ojca. Ci, którzy przeżyli doświadczenie źródłowe, odczuwają konieczność głoszenia go innym. Potrzeba misji jest konsekwencją miłości, która wypełniła ich serce i życie. Św. Paweł wyrazi to w następujący sposób:

„Albowiem miłość Chrystusa przynagla nas, pomnych na to, że skoro Jeden
umarł za wszystkich, to wszyscy pomarli. A właśnie za wszystkich umarł
[Chrystus] po to, aby ci, co żyja, już nie żyli dla siebie, lecz dla Tego, który
za nich umarł i zmartwychwstał. Tak więc i my odtąd już nikogo nie znamy
według ciała; a jeśli nawet według ciała poznaliśmy Chrystusa, to już więcej
nie znamy Go w ten sposób. Jeżeli więc ktoś pozostaje w Chrystusie, jest
nowym stworzeniem. To, co dawne, minęło, a oto wszystko stało się nowe.
Wszystko zaś to pochodzi od Boga, który pojednał nas z sobą przez Chrystu-
sa i zlecił na posługe jednania” (2 Kor 5, 14-18). „Biada mi, gdybym nie
głosił Ewangelii!” (1 Kor 9, 16).

Spotkanie ze Zmartwychwstałym i dar Ducha sprawiaja, że uczniowie całkowicie podporządkowuja swoje życie przepowiadaniu, tak by dokonywały się inne spotkania z Chrystusem, aktualizowane w czasie dzięki Duchowi Świętemu.

Teologia Nowego Testamentu naznaczona jest klimatem epiklezy, czyli wezwaniem skierowanym do Ducha Świętego. Dzięki Duchowi Świętemu, którego oczekiwano i który przyszedł ze swoją moca, urzeczywistnia się słowo ewangeliczne: „Kiedy przyjdzie Duch prawdy, On was poprowadzi do całej prawdy..." (J 16, 13). Podmiotem tej teologii jest autor natchniony, przeniknięty działaniem Ducha Świętego.

\section{Nowość życia: proroctwo}

Ta nieodparta konieczność przepowiadania, dzielenia się tym, czego uczniowie sami doświadczyli, prowadzi do tworzenia teologii najpierw głoszonej, a potem utrwalanej w formie słowa pisanego i zawartej ostatecznie w Nowym Testamencie. Nie jest ona jednorodna, bogactwo form wynika $\mathrm{z}$ różnorodności środowisk, $\mathrm{w}$ jakich była głoszona Ewangelia. Można jednak wyróżnić jej dwie zasadnicze formy.

Jedną $\mathrm{z}$ nich jest narracja, która dominuje w pierwszym okresie przepowiadania. Znamy najstarsze formuły kerygmatyczno-katechetyczne, w których wyrażona zostaje wiara w Jezusa jako Pana i Mesjasza: „Jezus jest Panem”, „Jezus jest Chrystusem” (Rz 10, 9; Flp 2, 11, Dz 2, 36; 10, 36, 1 J 2, 
22 itd.). Stwierdza się w nich, że prorok z Galilei, upokorzony przez ludzi, został wywyższony przez Boga i ustanowiony Panem i Chrystusem. Formy narracyjne nawiązują do wydarzenia paschalnego. Są one krótkie, ponieważ były adresowane do osób, którym były znane wydarzenia Wielkiego Tygodnia. Chodziło zatem jedynie o ich przywołanie w pamięci. Takimi są mowy Piotra w Dz 2, 14-36; 3, 12-26; 4, 8-12; 10, 34-43 i mowa Pawła z Dz 13, 16-41. Ich przepowiadanie zostaje zakotwiczone w historii, ma odniesienie do konkretnych wydarzeń.

Jednocześnie doświadczenie źródłowe skłania ludzi początków Kościoła do interpretacji swego życia i historii świata w świetle tego, co przeżyli we wspólnocie z Jezusem Chrystusem. Tak powstaje druga forma teologii pierwotnego Kościoła - bardziej refleksyjno-argumentacyjna. Wspomnienie wydarzeń minionych prowadzi do odkrycia rzeczywistej obecności Chrystusa i Jego Ducha we wspólnocie Kościoła, ale również, do odkrycia działania Boga w całej historii świata, którą doprowadzi do ostatecznego spełnienia. Paweł np. ukaże relację pomiędzy Prawem i Ewangelią, a tym samym ciągłość historii zbawienia narodu wybranego i nowego ludu, Jan natomiast uwypukli obecność Słowa na początku stworzenia, Jego zbawcze dzieło i działanie w historii, w której trwać będzie walka aż do ostatecznego zwycięstwa Pana.

Głęboka jedność świadectwa Nowego Testamentu, pomimo różnorodności form, niekiedy bardziej narracyjnych, a kiedy indziej bardziej refleksyjno-argumentacyjnych, wyraża się w trosce o wyrażenie prawdy o nowym początku życia każdego człowieka w Jezusie Chrystusie. U genezy teologii Nowego Testamentu odnajdujemy odniesienie do wydarzenia wciąż żywego, przeobrażającego wszystko. Chodzi o doświadczenie zmartwychwstałego Pana, które wciąż jest aktualne. Cały proces formowania się teologii nowotestamentalnej Bruno Forte określa jako:

„wysiłek przejścia od doświadczenia Słowa do słów, które wiernie przekazują Słowo, tak by, dzięki działaniu Ducha Świętego, od tych słów można było zawsze przejść do tego, co nowe, do ożywiającego doświadczenia spotkania ze Słowem boskiego adwentu"10.

W tym sensie teologia Nowego Testamentu jest proroctwem, które otwiera nowe drogi, przypomina o obecności Słowa i ukazuje „rzeczy przyszłe” (J 16, 13). Przedmiotem tej teologii jest „tajemniczy plan, ukryty przed wiekami”, „,boski plan zbawienia zrealizowany w Jezusie Chrystu-

\footnotetext{
${ }^{10}$ Por. B. ForTe, La teologia come compagnia, memoria e profezia, dz. cyt., s. 86.
} 
sie, w Nim mamy śmiały przystęp [do Ojca] z ufnością dzięki wierze w Niego" (Ef 3, 9 n.).

\section{Epoka patrystyczna - teologia symboliczna}

Okres patrystyczny to czas, którego pierwszoplanowymi postaciami byli ludzie o wielkich osobowościach. Za sprawą poprawności ich doktryny i głębokiej osobistej świętości Kościół uznaje ich za ojców w wierze; są oni niczym ogniwa łączące chrześcijan wszystkich czasów z pokoleniem apostołów, a poprzez apostołów - z Chrystusem. Chodzi o epokę o specjalnym znaczeniu w historii Kościoła i teologii. Doktryna Kościoła doznała w tym okresie godnego uznania rozwoju i wyrażała wiarę w starannie opracowanych formułach dogmatycznych. Ponadto był to czas, w którym Kościół wychodząc poza krąg świata żydowskiego, gdzie się narodził - stanął wobec kultury grecko-rzymskiej, chrystianizując ją od środka i potwierdzając $\mathrm{w}$ ten sposób możliwości, jakie ma wiara chrześcijańska do tego, aby przeniknąć każdą cywilizację i kulturę ${ }^{11}$.

Teologia Ojców Kościoła ma charakter symboliczny, ponieważ w otaczającej rzeczywistości i codziennych wydarzeniach uwypuklała znaki obecności Boga, który nie tylko zbawił człowieka, ale nieustannie prowadzi go do wspólnoty ze sobą. Jej autorami byli przede wszystkim biskupi - pasterze, którzy w trosce o dobro powierzonej im owczarni starali się jej dostarczyć duchowy pokarm. W gronie twórców teologii nie brakowało również osób świeckich.

\section{Chrystus spełnieniem tęsknoty za jednością}

Teologia patrystyczna rozwijała się w kontekście kultury hellenistycznej, naznaczonej tęsknotą za jednością, fundamentem i sensem wszelkiej różnorodności. Filozofia grecka, od Heraklita do Plotyna, stawiała podstawowe pytanie dotyczące pośrednictwa pomiędzy Bogiem i światem, które w języku Platona brzmiałoby: jak jedno (gr. "๕̌ - hén) może być pomyślane razem $\mathrm{z}$ wielością? Według filozofii stoickiej istnieje tylko jeden boski umysł świata, który wszystko utrzymuje i porządkuje. Umysł ten odzwierciedla się przede wszystkim w umyśle człowieka. Pytaniu o jedność towarzyszyła tęsknota za uwolnieniem się od materialności świata odczuwanej jako zniewolenie. Stąd poszukiwanie zbawienia poprzez poznanie - $\gamma \nu \hat{\omega} \sigma\llcorner\varsigma$ (gnósis).

${ }^{11}$ Por. J. L. Illanes, J. I. SARANYANA, Historia teologii, Kraków 1997, s. 16-18. 
Doktryna chrześcijan jawiła się jako prowokacja w kontekście tradycji greckiej: skazaniec, ukrzyżowany, człowiek uwikłany w świecie materii, a więc wielości, nie mógł być Bogiem. Hellenistyczne pragnienie jedności musiało być skonfrontowane z nowością Ewangelii. Pojawiło się pytanie: Co łączy Ateny z Jerozolimą, uznaną filozofię z nową nauką chrześcijańską?

Choć niektórzy autorzy chrześcijańscy rozwijali negatywną wizję świata, wyrażając pogardę dla jego wartości ziemskich, to jednak zasadniczo przeważyła postawa dostrzegania tego, co wartościowe w kulturze pogańskiej. Już teologowie chrześcijańscy II wieku byli świadomi, że Chrystus stanowi ostateczne spełnienie religijnych i intelektualnych tęsknot człowieka. W swojej koncepcji oparli się na myśli neoplatońskiej, przejęli intuicję kultury helleńskiej, że istnieje jakiś jeden fundament wszelkiej rzeczywistości, który Plotyn nazywał czasami Jedno tò étvaı (tó eínai), co w języku polskim wypada oddać przez słowo: „bycie”. Neoplatończycy uważali, że Jednia nie jest bytem, ale nie uprawnia to do stwierdzenia, że ona nie istnieje. Przeciwnie, Jednia jest pełnią istnienia dlatego, że darzy istnieniem wszystkie byty. Myśliciele chrześcijańscy przejęli przekonanie filozofów, że tylko to, co trwałe i niezmienne, może nosić miano bytu. Wszystko, co istnieje w świecie, o tyle może nazywać się bytem, o ile jest niezmienne. Nowość chrześcijaństwa polegała na nadaniu imienia temu fundamentowi bytów - jest nim Logos, odwieczne Słowo, które stało się człowiekiem. Chrystus jest początkiem i celem całego istnienia.

Uważano, że Pismo Święte zawiera pełnię mądrości, odpowiedź na wszystkie pytania. Przekonanie o wartości posiadanego Objawienia prowadziło teologów do odważnego spotkania i konfrontacji z pogańską kulturą i filozofią. W ten sposób rozpoczął się proces chrystianizacji świata hellenistycznego i rzymskiego. Wśród pierwszych jego promotorów wymienić należy filozofa Justyna († 165). W jego ujęciu Jezus Chrystus jest „Logosem” - Prawda, która nadaje sens każdej osobie i całej rzeczywistości historycznej; jest Słowem oświecającym „każdego człowieka, przychodzącego na ten świat”. A jest to świat, w którym już zostały rozsiane „ziarna Słowa"12. Tak oto kultura pogańska, w tym wszystkim, co w niej wartościowe, jawi się jako przestrzeń, w której Bóg przygotowywał świat na pełnię Objawienia zrealizowaną w Jezusie Chrystusie.

12 Św. Justyn, Apologia, 46; Dialog z Żydem Tryfonem, 61, wyd. pol. Pisma Ojców Kościoła, IV, Poznań 1926. 


\section{Kościół miejscem uprawiania teologii}

Rozpoczęty pomiędzy chrześcijanami a przedstawicielami kultury hellenistycznej dialog przyniósł wkrótce zagrożenie w zachowaniu tożsamości chrześcijańskiej. W drugiej połowie II wieku pojawiły się różne systemy gnostyckie. Ich reprezentanci uważali, że można być chrześcijaninem, a także rozwijać wiedzę na temat Boga, nie zważając na wiarę powszechnie wyznawaną w Kościele, a jedynie odwołując się do Pisma Świętego i tajemnego przekazu, znanego nielicznym „pneumatykom”, ludziom „duchowym”. Przeciwstawiając się subiektywnej interpretacji Biblii, św. Ireneusz i Tertulian podkreślali, że Kościół - jako wspólnota wszystkich wiernych zgromadzonych wokół biskupów - jest stróżem prawdy Objawionej. Jego ustne nauczanie i powszechnie praktykowane zwyczaje, a zwłaszcza liturgię, określili „kanonem wiary”13 i „regułą wiary” ${ }^{\text {, }}$. Tym sposobem rozstrzygnięto, że Kościół jest dla teologii kryterium hermeneutycznym ${ }^{15}$ :

„Obaliwszy więc wszystkich (heretyków) wygłaszających bezbożne nauki o naszym Stwórcy (...) trzymamy się nauki Kościoła, bo ona jest zawsze ta sama i trwa niezmiennie, a ma świadectwa proroków, apostołów i wszystkich uczniów (...). Otrzymaliśmy ją od Kościoła, więc jej strzeżmy, a ona zawsze za sprawą Ducha Świętego jakby w drogocennym naczyniu niby znakomity depozyt wiecznie jest młoda i odmładza samo naczynie, w którym się znajduje.

Kościołowi bowiem powierzono ten dar Boży (...), w nim zawiera się jedność z Chrystusem, tj. Duch Święty, zadatek niezniszczalności, wzmocnienie naszej wiary i drabina, po której wstępujemy do Boga. W Kościele postanowit Bóg apostołów, proroków i nauczycieli (por. 1 Kor 12, 28) i wszelkie inne działanie Ducha. Uczestnictwa w nim nie mają ci, co nie biegną do Kościoła, lecz błędnym przekonaniem i niegodziwym postępowaniem sami pozbawiają się życia.

Albowiem gdzie Kościół, tam i Duch Święty, a gdzie Duch Boży, tam Kościół i wszelka łaska - Duch zaś jest Prawdą"16.

${ }^{13}$ Św. IreneusZ, Adversus haereses, 1, 9, 4.

${ }^{14}$ Tertulian, Preskrypcja przeciw heretykom, 13-14, wyd. pol. Pisma Starochrześcijańskich Pisarzy, V, Warszawa 1970.

${ }^{15}$ Por. E. StanieK, Doświadczenie Kościoła w spotkaniu z gnoza, [w:] S. DobrzanowSKI (red.) New Age. Pseudoreligia, Kraków 1994, s. 33; T. DzIDEK, Pismo Święte a Tradycja - historia problemu, [w:] T. DZIDEK, B. SiEŃCZAK, J. D. SzCZurEK (red.), Tradycja w Kościele. Materiały z sympozjum zorganizowanego przez Papieska Akademię Teologiczna, Polskie Towarzystwo Teologiczne, Instytut Teologiczny Księży Misjonarzy w Krakowie, Kraków 1994, s. 103-105.

16 Św. Ireneusz, Adversus haereses, III, 24, 1; cyt. za: A. Bober, Antologia Patrystyczna, Kraków 1966, s. 48. 
Zdaniem Ireneusza biskupi jako następcy apostołów stanowią gwarancję przekazu prawdy:

„Dlatego należy słuchać zwierzchników w Kościele, którzy - jak udowodniliśmy - mają następstwo od apostołów. Z następstwem biskupstwa otrzymali oni niezawodny charyzmat prawdy (charisma veritatis certum), według upodobania Ojca" ${ }^{, 17}$.

\section{Próba syntezy}

Spotkanie z kulturą hellenistyczną, tak silnie naznaczoną poszukiwaniem jedności świata zaowocowało m. in. rozwojem systemów gnostyckich, w których połączono elementy filozofii, religii pogańskich i chrześcijaństwa. Było to intelektualne wyzwanie dla teologii, która nie mogła poprzestać na wskazaniu Jezusa Chrystusa jako zasady jedności wszystkiego, co istnieje. Przed Ojcami Kościoła stanęło zadanie opracowania chrześcijańskiej syntezy.

Potrzeba ta wynikała nie tylko z intelektualnej konfrontacji ze światem pogańskim, który szukał syntezy, ale także ze sposobu przeżywania wiary przez samych chrześcijan. Chodziło o przeżywanie wiary jako adwentu, czyli boskiego przyjścia. Bóg zszedł do człowieka przez Objawienie i w nim dał mu możliwość wznoszenia się do siebie. Wierzący podejmują tę drogę wznoszenia się ku wyżynom Boga. Służy temu nie tylko znajomość Boga w oparciu o Pismo Święte, liturgia, modlitwa, ale również codzienne życie, obowiązki rodzinne i społeczne, doświadczenie świata. Środkiem wiażącym te różne płaszczyzny była kontemplacja Pisma, umożliwiająca odkrycie obecności i woli Boga w życiu we wszystkich jego wymiarach. Chodzi tu o postrzeganie całej rzeczywistości w jej wymiarze symbolicznym, o umiejętność dostrzegania w niej znaków Bożego adwentu. One wyznaczają drogę do głębi wszystkiego, co istnieje, i warunkują nieustanne duchowe wznoszenie do Boga.

Te dwa czynniki: rywalizacja z myślą pogańską w tworzeniu satysfakcjonującego systemu oraz przeżywanie wiary $\mathrm{w}$ głębokiej symbiozie z życiem - zrodziły teologię Ojców ukierunkowaną na syntezę.

W tym właśnie kontekście należy interpretować wysiłek Orygenesa († ok. 253), który dał podstawy egzegezy Pisma Świętego, rozróżniając w nim sens literalny i alegoryczny. Twierdził, że wspólna wiara opiera się na

${ }^{17}$ Św. Ireneusz, Adversus haereses, IV, 26, 2; cyt. za: A. BoBER, Antologia Patrystyczna, dz. cyt., s. 50 . 
sensie literalnym tekstu biblijnego. Mimo to istnieje też poznanie wyższe „gnoza”, która za pośrednictwem medytacji szuka sensu duchowego. Właśnie ten sens rozświetla chrześcijaninowi drogę do Boga.

Orygenes dokonał pierwszej próby stworzenia systematycznej teologii spekulatywnej w dziele zatytułowanym $O$ zasadach (Peri Archôn). Pisze on we wstępie, że zamierza zbudować ,jakby ciało doktryny”. Rozprawa składa się z czterech ksiagg, których centralną ideą jest refleksja nad Trójcą Święta, w której wszystkie rzeczywistości stworzone osiagają swój sens. Orygenes jest świadomy, że na jego syntezę składają się twierdzenia, z których jedne są pewne, ponieważ zostały przekazane jasno przez apostołów, a inne stanowią plon ludzkiego umysłu bazującego w swych dociekaniach na Objawieniu:

„A trzeba wiedzieć o tym, że głosząc wiarę Chrystusową święci apostołowie o pewnych prawdach, uznanych przez nich za niezbędne, powiedzieli w sposób zrozumiały dla wszystkich wiernych [...]; co się zaś tyczy innych prawd, to powiedzieli wprawdzie o ich istnieniu, przemilczeli jednak sposób ich istnienia oraz pochodzenie; postapili tak zapewne w tym celu, aby wśród następnych pokoleń gorliwsi miłośnicy znaleźli sobie przedmiot ćwiczeń, w których mogliby przedstawić plon swego umysłu" $"$.

Tak oto już w myśli Orygenesa spotykamy zagadnienie stopnia pewności twierdzeń teologicznych. Wielki Aleksandryjczyk rozwijając swoją syntezę, formułując kolejne twierdzenia zaznacza, które z nich są bezwzględnie pewne dzięki autorytetowi samych apostołów, a które stanowią jedynie hipotezy - wynik poszukiwań $^{19}$.

\section{Wzajemność wiary i rozumu}

Czwarte i piąte stulecie stanowią prawdziwy „złoty wiek” patrystyki, możliwy dzięki połączeniu dwóch czynników: pokoju, jaki panuje od po-

${ }^{18}$ Orygenes, O zasadach, I, Przedmowa, 3, Kraków 1996, s. 52; Por. H. KüNG, Große christliche Denker, München-Zürich 1996, s. 55, T. D. LuKASZuK, Problematyka teologicznego poznania: stopnie pewności teologicznej, [w:] J. D. SzCZUREK, R. ZAWADZKI (red.) Sympozjum z okazji 15-lecia pontyfikatu Jana Pawła II, Kraków, 11-12 X 1993, Kraków 1994, s. $126-128$.

19 „Ja też mówię o tym z dużą obawą i ostrożnością, zastanawiam się raczej i rozmyślam, niż twierdzę cokolwiek na pewno. Określiłem przecież powyżej, co można stwierdzić z wyraźną pewnością; wydaje mi się, że w miarę swych umiejętności postąpiłem tak, rozprawiając o Trójcy Świętej; natomiast o sprawach, które stanowią obecny przedmiot moich rozważań, będę się starał mówić w formie hipotezy, a nie stanowczego twierdzenia"; ORYGENES, O zasadach, I, 6, 1. Por. H. Crouzel, Orygenes, Bydgoszcz 1996, s. 223-230. 
czątku IV wieku po wygaśnięciu prześladowań, oraz osiagniętej już przez myśl chrześcijańską dojrzałości.

Tę ostatnią w sposób szczególny reprezentuje teologia św. Augustyna († 430), która wywarła przemożny wpływ na całą łacińską teologię Sredniowiecza. W duchu Justyna i Orygenesa Augustyn posługuje się w swej twórczości teologicznej naukami wyzwolonymi i filozofią: „Dobry i prawdziwy chrześcijanin powinien zrozumieć, że prawda, niezależnie gdzie się znajduje, jest własnością Pana”20. Po swoim nawróceniu Augustyn jest przeniknięty pragnieniem pełnego spotkania z Bogiem, którego obecność, choć w sposób niepełny, została nam już dana przez wiarę. Wiara i rozumienie są drogą wiodącą do tego spotkania, dlatego nie można ich rozdzielać, wzajemnie się wspomagają: „Rozumiej, ażebyś wierzył i wierz, ażebyś rozumiał”21. Fraza intellige ut credas (,rozumiej, ażebyś wierzył”) oznacza, że ludzkie poznanie jest niezbędne, aby przyjąc i wyrazić wiarę. $Z$ kolei twierdzenie crede ut intelligas (,wierz, ażebyś rozumiał”) podkreśla, że rozumienie wiary zbliża do Boga, ponieważ umożliwia poznanie Go w horyzoncie już przyjętej wiary. W traktacie o Trójcy Świętej spotykamy taką oto zachętę:

„Niech (wierzący) przez modlitwę, rozmyślanie i święte życie starają się dojść do rozumienia, czyli do tego, żeby myślą widzieć (o ile można widzieć) to, co przyjmuja przez wiarę"22.

Uwypuklenie roli ,intelektu” nie redukuje poznania teologicznego do chłodnej dialektyki, zachowania obojętnego dystansu wobec przedmiotu poznania. Przeciwnie - jest to teologia, która wyrasta z inspiracji miłością osoby poszukującej pełnego szczęścia.

Koniec epoki patrystycznej zbiegł się w czasie ze schyłkiem starożytności. Jako punkt graniczny owej epoki - w odniesieniu do wschodniej części cesarstwa rzymskiego, a zatem do patrystyki greckiej - zwykło się wskazywać osobę św. Jana Damasceńskiego (ok. 675-749), chociaż trzeba zaznaczyć, że patrystyczny sposób uprawiania teologii trwał jeszcze długo w kręgach grecko-bizantyjskich.

\footnotetext{
${ }^{20}$ Św. Augustyn, O doktrynie chrześcijańskiej, II, 28, Warszawa 1989.

${ }^{21}$ Św. Augustyn, Contra acad., III, 20, 43: Serm., 43, 7, 9.

${ }^{22}$ Św. Augustyn, O Trójcy Świętej, XV, 27, 49, Kraków 1996.
} 


\section{Epoka scholastyczna - teologia dialektyczna}

Załamanie się struktury polityczno-społecznej cesarstwa zachodniego i założenie królestw germańskich wyznaczyło, już w V wieku, niewątpliwe zerwanie ciągłości kulturowej, politycznej i gospodarczej. Rozpoczynała się nowa epoka historii - Średniowiecze, którą większość uczonych rozciaga od 600 do $1500 \mathrm{roku}^{23}$. Był to czas, w którym Kościół zachował dziedzictwo intelektualne epoki starożytnej, a także wpłynął zasadniczo na ukształtowanie jedności kulturowej Europy. Istniała wtedy głęboka harmonia pomiędzy wiarą i rozumem, wynikająca $\mathrm{z}$ faktu, że intelektualistami byli zasadniczo zakonnicy.

W teologii rozwijała się wówczas tzw. teologia scholastyczna, która jednak wyraźnie przekroczyła granice końca epoki średniowiecznej i na gruncie Kościoła katolickiego była zasadniczo uprawiana jeszcze w okresie Renesansu i Baroku, czyli do końca XVII wieku.

\section{Znaczenie autorytetów}

W pierwszych wiekach Średniowiecza, między rokiem 750 a 1100, w uprawianiu teologii dominowała teologia monastyczna. Nawiązywała ona wyraźnie do epoki patrystycznej, od której przejęła przekonanie o wystarczalności Pisma Świętego w rozumieniu całej rzeczywistości oraz pragnienie tworzenia doskonałej symbiozy wiary i życia. Uprawianie teologii monastycznej polegało przede wszystkim na komentowaniu Pisma Świętego na sposób lectio, czyli medytacyjnej lektury tekstów biblijnych, wspomaganej komentarzami patrystycznymi. Autorytet Ojców Kościoła był gwarancją wierności wierze, jaką otrzymano i starano się przekazać.

Przy tej okazji powstawały zbiory tekstów patrystycznych, pomocne przy nauczaniu i zgłębianiu najtrudniejszych fragmentów Biblii. Z czasem były one coraz bardziej rozbudowywane i systematyzowane. Swą najbardziej znaną i wpływową formułę znalazły w Sentencjach Piotra Lombarda (ok. 1095-1160). Autor zręcznie zebrał w nich większość poglądów teologicznych swojej epoki, bardzo rzadko dorzucając osobiste wypowiedzi o przytaczanych poglądach.

W obrębie teologii monastycznej pojawił się jeszcze jeden nurt rozumienia teologii. Jego reprezentatywnym przedstawicielem jest św. Anzelm z Canterbury ( $\dagger$ 1109). Także on uznawał pierwszeństwo wiary, ale był przekonany o tym, że człowiek właśnie po to został obdarzony zdolnością 1988, s. 9.

${ }^{23}$ Por. M. D. Knowles, D. OBolensKy, Historia Kościoła, t. 2, 600-1500, Warszawa 
myślenia i pojmowania, żeby się starał możliwie doskonale przemyśleć i zrozumieć własną wiarę:

„Wielu prosiło mnie często i usilnie, ustnie i pisemnie, żebym spisał dla potomnych objaśnienie pewnego problemu naszej wiary, tak jak je zwykłem wykładać. Mówią mianowicie, że podoba się im moje rozwiązanie i uważają je za zadowalające. Nie stawiają tej prośby, żeby przez zrozumienie dojść do wiary, ale żeby cieszyć się zrozumieniem i rozważaniem tego, w co wierza. Chcą też, na ile potrafią «być zawsze gotowi do obrony wobec każdego, kto domaga się uzasadnienia tej nadziei, która jest w nas» $(1 \mathrm{P} 3,15)$ "24 .

Teologia jest intellectus fidei, pragnieniem zgłębiania rozumem tego, w co się już wierzy. Trzeba jednak podkreślić, że intelektualną dociekliwość umiał Anzelm zawsze połączyć z miłością do Boga, a także z szacunkiem dla Jego tajemnicy. O tej równowadze intelektu, miłości i wyczuciu tajemnicy pisze we wstępie do swego najgłośniejszego dzieła pt. Proslogion:

„Wyznaję, Panie, i dziękuję za to, że stworzyłeś we mnie też Twój obraz, bym pamiętając o Tobie, o Tobie myślał i Ciebie kochał! Został on jednak do tego stopnia zamazany naporem występków, tak bardzo zaciemniony oparami grzechów, iż nie może czynić tego, do czego został uczyniony, jeżeli Ty go nie odnowisz i nie naprawisz. Nie usiłuję, Panie, przeniknąć Twojej głębi, gdyż w żadnym razie nie przyrównuję do niej mego intelektu; pragnę jednak do pewnego stopnia zrozumieć Twoją prawdę, w którą wierzy i którą kocha moje serce. Nie staram się bowiem zrozumieć, abym uwierzył, ale wierzę, bym zrozumiał. Albowiem i w to wierzę, że jeżeli nie uwierzę, nie zrozumiem" 25 .

\section{Nowa metoda}

Około 1100 roku zaczął się pojawiać nowy styl uprawiania teologii. Została ona wyprowadzona $\mathrm{z}$ przestrzeni świątyni i zacisza klasztoru, a umiejscowiono ją w przestrzeni świeckiej, w szkołach katedralnych w Laon, w Chartres, w Paryżu, które stanowiły zapowiedź przyszłych uniwersytetów. Teologia, którą zaczęto uprawiać w owych szkołach odznaczała się wprowadzeniem teologicznych nowego stylu, który dał początek temu, co określamy dokładnie «teologią scholastyczną». Na jej powstanie złożyło się wiele różnorodnych czynników: rozwój społeczeństwa, podniesienie pozio-

${ }^{24}$ Św. AnZelm Z Canterbury, Cur Deus homo, I, 1, 91.

${ }^{25}$ Św. AnZelm Z CANterbury, Proslogion, 1, wyd. pol. Warszawa 1992. 
mu kultury i odkrycie na Zachodzie Europy Arystotelesa, którego upowszechnili w Hiszpanii żydowscy i arabscy uczeni.

Dziedzictwo myśli Arystotelesa okazało się rozstrzygające przez wniesienie nowego sposobu rozumowania - myślenia przez konfrontację dialektyczną negacji i twierdzenia. Ta forma rozumienia dialektycznego została przejęta przez elity intelektualne społeczeństwa zrodzonego $\mathrm{w}$ dobie rewolucji ekonomicznej, kulturowej i społecznej, której szczyt przypadł na XII wiek. W napięciu pomiędzy „tak” i „nie”, w napięciu pomiędzy przeciwstawnymi racjami i argumentami nauczono się postrzegać rzeczywistość w jej różnorodnych i złożonych aspektach. Ten sposób myślenia przeniknął także teologię. Do doktryny wiary zaczęto podchodzić bardziej racjonalnie poprzez powiązanie jej z logiką. To był początek scholastyki - „naukowej” teologii, która stanie się powszechna w zachodnim chrześcijaństwie.

Metoda scholastyczna, czyli dialectica, jak ją nazywano, była w swej logiczności i systematycznym zastosowaniu czymś nowym. Nie znaczy to jednak, że Ojcowie Kościoła nie uprawiali teologii opartej na rozumowym badaniu. Ich podejście do świętej doktryny (sacra doctrina) było jednak inne, można je określić jako syntetyczne. Dla patrystycznego sposobu uprawiania teologii literacka proza, ukształtowana według zasad retoryki, była nieodzowna. Ona wpływała na sposób myślenia i nadawała formę temu, co pisano. Tymczasem w scholastyce zaczęto podchodzić do teologii analitycznie. Dokonywano szczegółowej analizy pojęć, dogmatów, obrazów. Bernard z Clairvaux (1090-1153) nazwał później to zjawisko negatywnie ,kawałkowaniem" tajemnic wiary, które czytelnikowi, zamiast pogłębionego rozumienia, przynosi zagmatwaną obfitość pojęć obcych dla życia i Objawienia ${ }^{26}$.

Uosobieniem tej nowej racjonalności $\mathrm{w}$ teologii był Piotr Abelard (1079-1142). Mistrz Piotr był człowiekiem głębokiej wiary, ale także miłośnikiem dysput, wyjątkowym dialektykiem, lubującym się w kwestiach logicznych, które studiował w perspektywie tego, co dziś nazwalibyśmy logiką filozoficzną. To właśnie on w dziele Sic et non usystematyzował i przetarł szlaki nowej metodzie scholastycznej. Nauczył się bowiem korzystać z Sententiae Patrum, zbierać najbardziej znaczące wypowiedzi przekazywane przez tradycję patrystyczna, porównywać je między sobą i starać się w ten sposób odkryć prawdę ukrytą poza pozornymi sprzecznościami. Schemat metody scholastycznej wyglądał następująco: po pierwsze to, co zdaje się wyrażać dane stwierdzenie czy artykuł wiary (definitio); po drugie to, co wydaje mu się przeczyć (distinctio, divisio); i po trzecie - rozwiązanie pozornej antynomii (conclusio).

${ }^{26}$ Por. Św. Bernard z Clairvaux, Listy, 187-195, 326, 327, 330-338, PL 182. 
Stwierdzenie Abelarda, że „nie można wierzyć w to, czego się wcześniej nie zrozumiało"27 właściwie charakteryzuje uprawianą przez niego teologię. Chodziło mu o to, aby wypowiedzi na temat wiary były zrozumiałe dla tego, który je głosi. Tym samym występował przeciw biernemu, niemal mechanicznemu powtarzaniu niezmiennych, dogmatycznych formul, które w swej treści dla wielu pozostawały obce. Jego zdaniem, prawdziwe głoszenie wiary nie polega na powtarzaniu przekazanych formuł, lecz na wyjaśnieniu słuchaczom ich znaczenia. Co więcej, brak wniknięcia w ich treść świadczy, zdaniem mistrza Piotra, o lenistwie w myśleniu ${ }^{28}$.

\section{Napięcie pomiędzy teologią symboliczną i dialektyczną}

Nowa metoda scholastyczna, a także jej forma literacka, natrafiła na opór teologii tradycyjnej, czyli monastyczno-symbolicznej, w obronie której stanął głównie św. Bernard z Clairvaux. Odrzucenie dialektyki wynikało $\mathrm{z}$ jego temperamentu. Był on bowiem obdarzony zdolnościami artysty, nie filozofa w scholastycznym sensie. Jego rezerwa do nowej metody wynikała również z tradycji. Cystersi przeżywali wówczas reformę życia zakonnego, rozumianą jako powrót do autentycznych źródeł. Stąd Ojcowie Kościoła stanowili dla nich przykład, jak uprawiać teologię. Bernard tworzył w ich stylu. Nie oznacza to jednak, że nie był racjonalistą. Starał się jednak łączyć rozumową refleksję nad wiarą z religijnym doświadczeniem, poczuciem obecności $\mathrm{Boga}^{29}$.

Swą negatywną postawę wobec Abelarda i nowej teologii scholastycznej Bernard wyraził w dziele Tractatus de erroribus Abelardi. Krytykę Abelarda zaczyna od cytatu z jego dzieła: „Jakiż pożytek przynosi doktrynie mówienie, jeśli to, czego chcemy nauczać, nie może być wyrażone w zrozumiały sposób?"30. Bernard uważa, że istnieją takie prawdy, które znajdują się ponad rozumem. Jego zdaniem, dziedziny rozumu i wiary są ściśle wytyczone. Rozum ma swe granice, poza którymi zaczyna się władza wiary. Granice te nie powinny być przekraczane, gdyż byłoby to bezbożnością, bra-

${ }^{27}$ Por. Bernard z Clairvaux, Kazania do Pieśni nad Pieśniami, 36, 3; PL 183, 968; C. Rocchetta, La teologia e la sua storia, [w:] C. Rocchetta, R. Fisichella, G. Pozzo, La teologia tra rivelazione e storia, Bologna 1989, s. 53.

${ }^{28}$ Por. E. GÖSSMANN, Glaube und Gotteserkenntnis im Mittelalter, [w:] M. ScHMAUS, A. Grillmeier, L. SCHEFFCZYK (red.), Handbuch der Dogmengeschichte, I/2b, Freiburg-Basel-Wien 1971, s. 14-19.

${ }^{29}$ Por. G. B. Winkler, Einleitung, [w:] Bernhard von Clairvaux, Sämtliche Werke lateinisch/deutsch, t. I, Innsbruck 1990, s. 15-37.

${ }^{30}$ Por. Bernard z Clairvaux, Traktat o błędach Abelarda, 1, PL 182, 1053 A-C. 
kiem czci, niemal profanacją Bożej tajemnicy. Dla Bernarda filozofia nie jest niezbędną pomocą $\mathrm{w}$ dojściu do poznania Boga, wręcz przeciwnie, stanowi raczej utrudnienie, będąc często źródłem pychy.

Historia pokazała, że zwycięzcą tego sporu został jednak Piotr Abelard, ponieważ stosowana przez niego nowa metoda stała się z czasem powszechna w teologii, przynosząc wiek później imponujące owoce. W tym miejscu trzeba jednak zapytać, co tkwiło u korzeni tego sporu. Nie da się go wytłumaczyć jedynie różnicą zapatrywań na sposób uprawiania teologii ani wzajemną niechęcią przesłaniającą obiektywne spojrzenie tych dwóch wielkich osobowości. Przyczyny sporu należy upatrywać w odmiennym rozumieniu wiary. Piotr Abelard łączył ją z rozumem, Bernard z miłością. W konsekwencji pierwszy patrzył na teologię przez pryzmat rozumu, drugi - miłości ${ }^{31}$.

Zapoczątkowany w XII wieku proces przyniósł na Zachodzie rozkwit uniwersytetów, a w nich - teologii. Wiadomo, że zarówno szkoły katedralne, jak i uniwersytety zachowywały początkowo charakter wspólnot wiary poszukujących prawdy. Jednakże umiejscowienie teologii w sali wykładowej pociagnę̧o za sobą proces, z czasem coraz bardziej się ujawniający, jej uprawiania poza pierwotnym i naturalnym środowiskiem, jakim była wspólnota wiary. Wprowadzi to odmienne ujmowanie relacji teolog - Bóg. Uprawiający teologię przestaje traktować Boga jako podmiot swych osobowych relacji (subiectum), lecz jako przedmiot swoich intelektualnych dociekań. $\mathrm{W}$ ten sposób dochodzi do zasadniczego wynaturzenia teologii. Odarta z miłości, staje się wiedzą dla samej siebie, wiedzą, która już nie prowadzi do Boga i niewiele ma wspólnego z duchowym trwaniem przy Panu.

Św. Bernard przez wielu historyków teologii jest postrzegany jako myśliciel niesystematyczny, przez innych jako konserwatywny, bo idący pod prąd rozwijającej się scholastyki. Dla wszystkich jednak jest klasykiem w ukazaniu podmiotowej relacji, jaka zachodzi w teologii pomiędzy poznającym człowiekiem i poznawanym Bogiem ${ }^{32}$. Przypomina on o tym, że pomimo przeniesienia teologii z obrębu kościoła i klasztoru do neutralności akademickiej sali, winna być ona studiowana jako nauka odpowiadająca duchowej praktyce i rozumiana jako wymaganie życia.

W świetle zarysowanego wyżej sporu o styl uprawiania teologii, bardziej zrozumiała staje się odmienność teologii Zachodu i Wschodu. Podczas gdy pierwsza wejdzie w nowy etap - scholastyczny, przejmując dialektykę

${ }^{31}$ Por. E. Gössmann, Glaube und Gotteserkenntnis im Mittelalter, dz. cyt., s. 19-20.

${ }^{32}$ Por. U. KöPF, Bernard von Clairvaux (1090-1153), [w:] H. FrIES, G. KretschMAR (red.), Klassiker der Theologie, t. I, München 1981, s. 193-197; E. GössmanN, Glaube und Gotteserkenntnis im Mittelalter, dz. cyt., s. 72-73. 
jako swoją metodę, druga pozostanie silnie związana z dziedzictwem patrystycznym, zachowując swój kontemplacyjny i symboliczny charakter.

Trzeba jednak dodać, że obydwie tradycje nie zatraciły punktów stycznych. Metodę dialektycznego myślenia można np. dostrzec w myśli wielkiego teologa i mistyka Wschodu - Grzegorza Palamasa. Nurt teologii monastyczno-symbolicznej był nadal kultywowany w szkole franciszkańskiej ze św. Bonawenturą na czele.

\section{Systematyczne opracowanie statusu teologii}

Powstały i rozwijany w łonie instytucji akademickich - w szkołach katedralnych, potem na wydziałach teologicznych uniwersytetów - scholastyczny sposób uprawiania teologii ulegał ewolucji, będąc źródłem coraz obszerniejszych i przygotowywanych z coraz większą głębią teoretyczną rozwinięć spekulatywnych, stał się z czasem jednym ze szczytowych osiagnięć w powszechnej historii myśli. Wykład akademicki, ze swymi wymaganiami nie tylko naukowymi, ale i dydaktycznymi, skłaniał do wypracowywania syntez i spowodował pojawienie się Summae, które stanowią niewątpliwie jeden z najbardziej charakterystycznych wyrazów twórczości teologicznej wieków średnich ${ }^{33}$.

W historii teologii mówi się o „rewolucji albertyńsko-tomistycznej”. Opierała się ona na przejęciu metafizyki Arystotelesa, która dostarczyła średniowiecznym myślicielom - jednocześnie filozofom i teologom - narzędzi do rozumienia oraz ujmowania świata i Objawienia w ich jedności. Chodzi tu o pojęcia potencji i aktu, materii i formy, przyczynowości, substancji i przypadłości, które na długo zapanowały w teologii łacińskiej. Kategorie te, zwłaszcza możności i aktu, zostały wymyślone, by wyjaśnić zmienność bytów jednocześnie zachowujących swą tożsamość. Trzeba jednak dodać, że były one bardziej przydatne do statycznego ujmowania rzeczywistości. Wymykał się im natomiast dynamiczny wymiar procesów zachodzących w świecie i w człowieku.

Y. Congar zauważa, że Ojcowie Kościoła, a zwłaszcza prekursorzy scholastyki uznawali wprawdzie rozum jako siłę swoista, ale tylko w tej mierze, w jakiej służył ,gnozie”, to znaczy wierzący mogli się nim posługiwać $\mathrm{w}$ poznawaniu, a nawet $\mathrm{w}$ dowodzeniu tego, co przyjmowali wiara. A zatem miało to być poznanie, które służy wierze. Św. Albert i św. Tomasz, przejmując od Arystotelesa wiedzę o strukturze rzeczywistości, odróżniali

${ }^{33}$ Por. P. P. GILBERT, Wprowadzenie do teologii Średniowiecza, Kraków 1997, s. 122 -126 . 
dwie dziedziny: dziedzinę prawd udowadnianych przez rozum oraz takich, które człowiek może poznawać tylko przez Objawienie ${ }^{34}$. Tym sposobem, jak celnie zwraca na to uwage Congar, Tomasz „umożliwi nam nawiązanie dialogu z ludźmi pochłoniętymi poznawaniem rzeczy, pogrążonymi w naukach przyrodniczych i technicznych świata, który poznają i kochają dla niego samego"35.

Wytyczenie granic i autonomii teologii oraz innych nauk umożliwiło Tomaszowi sprecyzowanie przedmiotu i metody samej teologii. Przedmiot formalny quod teologii, a raczej jej subiectum, stanowi Bóg i cała rzeczywistość w jej odniesieniu do Stwórcy:

„Otóż wiara stanowi przedsmak owego poznania, które nas w przyszłości uczyni błogosławionymi. (...) To zaś uszczęśliwiające poznanie wiary koncentruje się na dwóch prawdach: tego co dotyczy Boskości Trójcy oraz człowieczeństwa Chrystusa. Toteż mówił do Ojca: «To jest życie wieczne, aby poznali Ciebie, prawdziwego Boga, i Tego któregoś posłał, Jezusa Chrystusa». Zatem całe poznanie wiary koncentruje się wokół tych dwóch, to znaczy wokół Boskości Trójcy i wokół człowieczeństwa Chrystusa; i nic w tym dziwnego, gdyż człowieczeństwo Chrystusa jest drogą prowadzącą do Boskości. Trzeba więc w drodze do boskości poznawać drogę prowadząca do celu, a i w ojczyźnie dziękczynienie nie byłoby dostateczne, gdybyśmy nie mieli poznania drogi, przez którą zostaliśmy zbawieni. Dlatego też Pan mówił uczniom: «I wiecie, dokąd Ja idę, i drogę znacie».

„Otóż co do Boskości, trzy [tematy] należy poznać: po pierwsze - jedność istoty, po wtóre - Trójcę Osób, po trzecie - dzieła Boskie" ${ }^{36}$.

Przedmiot formalny quo natomiast, dzięki któremu wiedza teologiczna jest w ogóle możliwa - stanowi Objawienie. Wiedza, poznawanie naukowe istoty rzeczy, to znaczy wiązanie w sposób konieczny właściwości z podmiotem, skutków z przyczyną, wniosków z założeniami - jest absolutną doskonałością istoty rozumnej. Św. Tomasz stosuje te założenia do teologii, którą określa jako wiedzę spekulatywną. W ten sposób próbuje jak najbar-

${ }^{34}$ Por. Y. M. Congar, Wiara i teologia, [w:] Tajemnica Boga, Poznań 1966, s. 191-192 .

${ }^{35}$ Y. M. CONGAR, tamże, s. 193.

${ }^{36}$ Streszczenie teologii, I, 2, [w:] Dzieła wybrane, Poznań 1984, s. 11-12; „W nauce świętej traktuje się o wszystkim w relacji do Boga, ponieważ albo te rzeczy są Bogiem (istota, atrybuty, osoby), albo też są one powiązane z Bogiem jako ich zasadą, czyli ich początkiem i celem (stworzenia, akty ludzkie, prawa, łaska, cnoty, sakramenty); Suma teologiczna, I, q. 1, a 7 . 
dziej zobiektywizować teologię. Do tej pory bowiem była ona czasami rozumiana jako osobiste, subiektywne poszukiwanie Boga ${ }^{37}$.

Kiedy w okresie dojrzałej scholastyki, w XIII wieku, postawiono pytanie o naukowość teologii, wartość „wiedzy boskiej” nie była przez nikogo kwestionowana. Pytano więc właściwie o to, czy poznanie teologiczne można umieszczać na tej samej płaszczyźnie z innymi dziedzinami poznania - to znaczy, czy teologia może się ,zniżyć” do roli jednej z gałęzi poznania naukowego. Odpowiedź była pozytywna - Tomasz z Akwinu uznał teologię jako naukę w ścisłym tego słowa znaczeniu. A mając poczucie wybitnej wartości teologii, nazwał ją królową nauk ${ }^{38}$.

Tomasz rozumiał naukę tak, jak to było powszechne w jego czasach, a więc w duchu Arystotelesowskim. Arystoteles i jego kontynuatorzy, zwracając uwagę na pełnię, jaką osiaga poznanie kiedy ujmuje przedmiot przez dostrzeganie nie tylko jego istnienia faktycznego, lecz także wyjaśnianie poprzez sięgnięcie do jego korzeni, określili naukę jako poznanie pewne przez przyczyny. Ponadto Arystoteles zauważył, że nauki są uporządkowane i zhierarchizowane. W niektórych przypadkach ta hierarchizacja dotyczy tego, co funduje jakąś naukę - jej założenia: podczas kiedy jedne nauki wychodzą od zasad ewidentnych, podlegających obserwacji, czy też poznaniu bezpośredniemu, inne wywodzą się od założeń nieewidentnych przez się i będących przedmiotem wykazywania w innych naukach. Np. fizyka opiera się na założeniach, które wykazuje matematyka, zaś optyka opiera się na założeniach pochodzących $\mathrm{z}$ geometrii. Tak więc istnieją nauki podporządkowane i podporządkowujące.

W obrębie tak zdefiniowanej nauki i jej klasyfikacji św. Tomasz stwierdza, że ktoś kto uprawia równocześnie naukę podporządkowaną i podporządkowująca, np. fizykę i matematykę, dysponuje wiedzą w stanie doskonałym, ponieważ założenia, w oparciu o które pracuje jako fizyk, może zweryfikować jako matematyk. Inaczej rzecz się ma, kiedy naukowiec uprawia jedynie naukę podporządkowaną, to znaczy taką, w obrębie której nie jest w stanie sprawdzić jej założeń. Taki układ implikuje akt wiary, na mocy której przyjmuje się, bez sprawdzenia, konkluzje do których doszedł ktoś, kto uprawiał naukę wyższą. W tym akcie wiary nie ma jednak niczego nieprawomocnego, niesłusznego - rozum ludzki jest ograniczony i aby się rozwijać, potrzebuje oparcia się na poznaniu, którym dysponują inni ${ }^{39}$.

${ }^{37}$ Por. Y. M. Congar, Wiara i teologia, dz. cyt., s. 191-192.

${ }^{38}$ Por. T. WĘCŁAWSKI, Wstęp do teologii (maszynopis), Poznań, brak daty, s. 13.

39 Por. R. Latourelle, Théologie science du salut, Bruges-Paris-Montréal 1968, s. $23-25$. 
Takie są rozważania, które przedstawia św. Tomasz, dotykając statusu epistemologicznego teologii. Pozwalają mu one dojść do następujących konkluzji:

- Teologia, zawierając w uporządkowanej strukturze treść wiary i przyczyniając się do rozwoju jej rozumienia, jest nauką w sensie właściwym i prawdziwym. Rzecz jasna, nie posiada oczywistości swych założeń, mających źródło w Objawieniu. Sytuacja teologii jest analogiczna do innych nauk podporządkowanych, które są uzależnione od nauk wyższych. Teologia jest zatem nauką $\mathrm{w}$ stanie niedoskonałym - zakłada nieustanne odnoszenie się do nauki wyższej, którą jest wiedza samego Boga.

- Teolog zatem zweryfikuje oczywistość swych założeń w wizji błogosławionej, to znaczy w wieczności ${ }^{40}$.

Tomasz z Akwinu jest autorem najbardziej znanej syntezy teologicznej. Jego Summa theologiae dzieli się na trzy wielkie cześci: o Bogu, o życiu moralnym i o Chrystusie i sakramentach. Części składają się z kwestii, a te z kolei dzielą się na artykuły, w których poszczególne rozważane zagadnienia podejmowane są według stałego schematu:

- postawienie problemu $($ utrum $\ldots=$ czy ...);

- wyrażenie wattpliwości i argumenty przeciw rozważanemu sformułowaniu (videtur quod non = wydaje się, że nie);

- argumenty za rozważanym sformułowaniem (sed contra dicitur $=$ jednakże przeciw temu powiada się);

- odpowiedzi mistrza zawierające proponowane przezeń rozwiązania w nawiązaniu do podniesionych uprzednio wątpliwości i dyskusję z przytoczonymi argumentami (respondeo $=$ odpowiadam $)^{41}$.

Teologia scholastyczna w swoim szczytowym okresie rozwoju - w wydaniu takich mistrzów, jak Tomasz czy Jan Duns Szkot - stanowi przykład symbiozy niezwykle wyrafinowanego rozumu i głębokiej wiary. Cechuje się niezwykle twórczym i zdyscyplinowanym myśleniem oraz odważnym wykorzystaniem wszelakich, nie tylko chrześcijańskich, owoców ludzkiej myśli. Rozwija jednocześnie swoje subtelne spekulacje w kontekście żywej duchowości. Ten sposób uprawiania teologii wiąże się jednak i z pewnymi niebezpieczeństwami - z pokusą nadmiernej racjonalizacji i systematyzacji oraz z ryzykiem oderwania myślenia tak od życia duchowego, jak i codziennych doświadczeń chrześcijan. Niestety, wspomniane negatywne możliwości

${ }^{40}$ Por. Św. Tomasz, Suma teologiczna, I, q. 1, a 2; De Veritate, q. 14, a 9, ad 3.

${ }^{41}$ Por. T. WĘCŁAWSKI, Teologia, art. cyt., s. 251. 
ujawniły się bardzo wyraźnie w późniejszych czasach, gdy w zmienionej rzeczywistości społecznej teologowie znacznie mniejszego formatu niż np. Akwinata, próbowali dość mechanicznie naśladować wielkich mistrzów Średniowiecza.

\section{E. Epoka nowożytna - teologia pozytywno- -kontrowersyjna}

Świat średniowieczny charakteryzował się pewną harmonią polityki, religii i myśli. Epoka nowożytna przynosi jej rozkład. Począwszy od XV wieku, pojawia się nowa wizja świata i człowieka. W średniowiecznej koncepcji człowiek został wpisany jako element w potężny wszechświat. W przypadku humanizmu jesteśmy świadkami odwrócenia sytuacji: człowiek stał się centrum koncepcji świata i osią fillozofii. Humanizm podkreśla subiektywizm jednostki, a także autonomię rozumu. Inny sposób podejścia do kultury greckiej, z której czerpano natchnienie dla nowej wizji człowieka, sprzyjał z jednej strony powstaniu nauki filologicznej, a z drugiej - nadawał studiom nad klasykami wartość normatywną dla nowego ideału życiowego. W epoce nowożytnej obserwujemy zjawisko zderzania się różnych tendencji w uprawianiu teologii, które łączy jednak bardzo mocne zakotwiczenie w historii.

\section{Krytyka scholastyki i subiektywizm nowożytny}

W „nowych czasach” zaczęto krytycznie podchodzić do późnej scholastyki, rozwijanej od 1300 do 1500 roku. Zbytnie akcentowanie rozumu sprawiło, że świadectwa Pisma Świętego i tradycji zostały przesunięte na dalszy plan. Najpierw formułowano tezy, do których dochodzono w sposób rozumowy, a potem wydobywano niektóre teksty z Biblii i tradycji, ażeby wykazać prawdziwość uprzednio wypracowanej tezy. Tym sposobem teologia przestała być racjonalnym przyjęciem tajemnic, a stała się konstrukcją służącą wydobyciu nowych konkluzji, które niewiele miały wspólnego $\mathrm{z}$ wiarą. Refleksja rozwijana w dyskusjach między szkołami gubiła się nieraz w roztrząsaniu kwestii dalekich od centralnych problemów wiary.

Powrót do starożytności przyniósł również ożywione zainteresowanie pismami Ojców Kościoła. W pierwszych wiekach chrześcijaństwa teologiczna twórczość rozwijała się najczęściej w ścisłym związku z liturgią. Komentarze do Pisma Świętego stanowily owoc homilii, traktaty na temat sakramentów powstawały jako katechezy wprowadzające katechumenów 
w sakramenty wtajemniczenia. Ten związek teologii z liturgią, a także wpływ filozofii platońskiej (w której symbol nie przeciwstawiał się rzeczywistości, ale ją wyrażał) sprawił, że Ojcowie Kościoła posługiwali się w swej twórczości językiem symbolicznym. Był to język, który pozwalał wyrażać realne spotkanie z tajemnicą, dokonujące się dzięki wierze.

Mając to na uwadze, Erazm z Rotterdamu († 1536) postulował studium Pisma i dokumentów patrystycznych w kontekście historycznym i w ich sensie literalnym, a także akcentował konieczność znajomości języków biblijnych. Uwypuklał jednocześnie transcendencję Boga i spraw boskich.

$\mathrm{Z}$ kolei Marcin Luter ( $†$ 1546) doszedł w swym sposobie rozumienia teologii do skrajnego subiektywizmu. Według niego, istotą chrześcijaństwa jest głoszenie zbawienia w Chrystusie. Tym, co liczy się naprawdę jest przyjęcie tej nowiny:

„(...) nie wystarcza i nie jest rzeczą chrześcijańską opowiadać o dziełach Chrystusa w sposób historyczny, jakby o jakichś tam wydarzeniach, których znajomość wystarcza nam jako przykład do kształtowania swego życia, jak to głoszą ci, co obecnie uchodzą za najlepszych. Tym gorzej, jeżeli się całkowicie o Chrystusie zamilczy, a zamiast tego naucza o ustawach ludzkich i o dekretach ojców. Niemało już jest takich, którzy w tym celu głoszą Chrystusa lub o Nim wykładająa aby poruszyć ludzkie uczucia do litości nad Chrystusem i do oburzenia na Żydów oraz inne podobne dziecinne niedorzeczności głoszą. Należy zaś głosić Chrystusa w tym celu, aby została wzbudzona wiara w Niego tak, żeby nie tylko to był Chrystus, lecz aby był On twoim i moim Chrystusem, by w nas wzbudzał to, co się o Nim mówi i kim się On nazywa"42.

Wszystkiego innego, co nie jest Chrystusem, należy zaniechać: Prawa odrzuconego już przez Pawła i naszych rozróżnień filozoficznych. Jedynie w Piśmie Świętym i w lekturze Ojców, a przede wszystkim św. Augustyna, winniśmy szukać nauki zbawienia. Przez ograniczoność naszego stworzenia, a także przez grzeszny stan ludzkiej natury, poznanie racjonalne nie posiada żadnej wartości dla wierzącego. Teologia winna być prawdziwą pobożnością. Luter uważał, że filozofia i inne nauki są pomocne jedynie jako przygotowanie ducha do kontemplacji, ale nie są użyteczne w racjonalnej systematyzacji wiary ${ }^{43}$. Istote swojej teologii reformacyjnej wyraził on $\mathrm{w}$ tezie o usprawiedliwieniu bezbożnych, dokonującym się jedynie $\mathrm{z}$ wiary, tylko w ufności do Jezusa Chrystusa, co wyraził w articulus stantis et cadentis Ecclesiae (artykuł, który stanowi o trwaniu albo upadku Kościoła). Reforma-

${ }^{42}$ M. LUTER, O wolności chrześcijańkiej, Warszawa 1991, s. 23-24.

${ }^{43}$ Por. B. HÄGgLund, Geschichte der Theologie, München 1983, s. 168-191; J. ESPEJA PARDO, Para comprender mejor la fe. Una introducción a la teología, dz. cyt., s. 83-84. 
torzy (M. Luter, H. Zwingli, F. Melanchton) wskazywali na potrójne solus usprawiedliwienia: solus Christus, sola gratia, sola fide; owego „tylko” nie sposób odłączyć od pojednania z Chrystusem. Usprawiedliwienie związane było także z konsekwentnym rozróżnieniem między Prawem a Ewangelią ${ }^{44}$.

\section{Scholastyka zakotwiczona w źródłach historycznych: systematyzacja miejsc teologicznych}

Trzeba jednak przyznać, że również typowa scholastyka renesansowa, rozwijająca się od początku do połowy XVI wieku, charakteryzuje się wzbogaceniem metody scholastycznej ówczesnym, wywodzącym się z renesansowego humanizmu, zainteresowaniem literaturą i historią, czego świadectwo odnajdujemy między innymi w dziełach dominikanina Melchiora Cano (1509-1560). Jego znaczenie polega na ukazaniu, że siła dowodzenia w refleksji teologicznej nie wypływa z punktu widzenia jej zawartości, lecz z faktu, że opiera się ona na prawdach objawionych. Nie treść decyduje o jej teologicznym charakterze, lecz stan jej objawienia. W konsekwencji wierzy się nie dlatego, że prawdy o Wcieleniu, o Eucharystii, o Zmartwychwstaniu wydają się wzniosłe czy oczywiste, lecz wierzy się, ponieważ prawdy te zostały objawione. W swoim dziele życia - De locis theologicis - podjął zagadnienie hierarchii miejsc, czyli źródeł, z których teologia czerpie wiedzę.

Systematyzacja ta jest ogromnie interesująca, jej pierwowzorów można dopatrzeć się w arystotelesowskim studium typów, a przede wszystkim w Sumie teologicznej św. Tomasza ${ }^{45}$. Rzeczywiście, Akwinata zastanawiając się nad argumentacyjnym charakterem teologii, wskazuje na różne poziomy argumentacji: ze względu na autorytet Pisma Świętego, ze względu na autorytet doktorów Kościoła i zgodnie z autorytetem filozofów. Oczywiście, nie wszystkie autorytety mają w oczach Tomasza tę samą wartość.

Melchior Cano odczuwał potrzebę szerszego zajęcia się tym tematem w kontekście polemiki z reformacją. W ten sposób powstało De locis, napisane błyskotliwą, humanistyczną łaciną, charakteryzujące się zwartą argumentacją spekulatywną, opartą na bogatej erudycji. Hiszpański teolog usystematyzował dziesięć miejsc poznania teologicznego. Podzielił je na dwie zasadnicze grupy: teologiczne w ścisłym tego słowa znaczeniu i pomocnicze. W grupie pierwszej wyróżnił: dwa miejsca „własne, konstytutywne”: Pismo Święte i tradycje Apostołów; pięć miejsc „własnych, wyjaśniających”: Ko-

${ }^{44}$ Por. A. NAPIÓRKOWSKI, Usprawiedliwienie grzesznika. Czy potępienia doktrynalne z XVI w. zachowujq nadal swojq ważność?, Kraków 1998, s. 88-93.

${ }^{45}$ Por. I, q. 1, a. 8, ad 2. 
ściół katolicki, sobory, Kościół rzymski, Ojców Kościoła i teologów scholastycznych. Obok miejsc teologicznych, Cano wyodrębnił trzy miejsca „pomocnicze": rozum, filozofów i prawników oraz historię z jej ludzkimi tradycjami.

Jego dzieło, cieszące się w ciągu dziejów wielkim powodzeniem, można dziś w pewnych szczegółach uzupełnić, jednakże w swych zasadniczych konturach zachowuje ono aktualność do naszych czasów ${ }^{46}$.

\section{Triumf subiektywizmu}

Zapoczątkowany w dobie Renesansu, proces subiektywizmu w myśleniu rozwijał się. Wiek XVII jest pod wieloma względami czasem poważnych przemian. Na scenie zajętej dotychczas głównie przez tradycję scholastyczną, zaczynają dominować inne nurty myślowe, szczególnie wywodzący się z Francji racjonalizm i - mający źródła anglosaskie - empiryzm. Tendencje sceptyczne czy naturalistyczne, powstałe $\mathrm{w}$ dawniejszych epokach, ale o bardzo ograniczonym dotąd polu oddziaływania, zyskują teraz na sile. Sprzyja im kryzys świadomości wywołany ciężkim doświadczeniem wojen religijnych, które wstrząsnęły Europa. Tak został przygotowany grunt pod zerwanie pewnej ciągłości duchowej i intelektualnej, które stało się oczywiste w wieku XVIII: ludność Europy pozostała w większości chrześcijańska, jednakże w warstwach wykształconych rozpowszechniła się, a nawet zaczęła przeważać, wyraźna tendencja do niewiary albo do sceptycyzmu i obojętności religijnej.

W dobie Oświecenia rozwinęło się pojęcie religii naturalnej, pozostające w ścisłym związku z filozoficzno-metafizycznym poglądem, który zwykło się określać mianem deizmu, a więc z koncepcją, wedle której wszechświat zakłada rzeczywistość Boga. Dokonał On stworzenia świata, ale ten, raz stworzony, funkcjonuje i rozwija się autonomicznie, zgodnie z prawami, które rządzą jego dynamiką bez żadnej późniejszej interwencji boskiej. Bóg jest jedynie - według metafory użytej przez Voltaire'a - „wiecznym geometrą”, „wielkim zegarmistrzem wszechświata”. Religia naturalna, o której mówi myśl epoki Oświecenia, nie zakłada żadnej życiowej relacji między człowiekiem a Bogiem. Dlatego wielu przedstawicieli oświeconego racjona-

${ }^{46}$ Por. J. L. Illanes, J. I. SARANYANA, Historia teologii, dz. cyt., s. 200-204; E. VILANOVA, Historia de la teología, t. II, Prerreforma, reformas, contrarreformas, Barcelona 1989, s. 611-614; M. SECKLER, Die ekklesiologische Bedeutung des Systems der "Loci theologici”, [w:] „Theologisches Jahrbuch” 1989, s. 97-125. 
lizmu redukuje religię jedynie do wymiaru moralnego, zaś inni pojmują ją jako kontemplację natury.

Tym tendecjom przeciwstawił się m.in. Friedrich Daniel Ernst Schleiermacher (1768-1834), pastor i profesor teologii. Chciał on ukazać specyfikę religii, unikając redukowania jej do deizmu (Oświecenie), do moralności (Kant) i przeciwstawiając się jej pochłnięciu przez filozofię (Hegel). W swej koncepcji odwołał się do uczucia (Gefühl).

Ze względu na swą naturę, w odróżnieniu od poznania koncepcyjnego, które dzieli i rozdrabnia, uczucie - stwierdza Schleiermacher - może uchwycić wszystko w jedności. Zawiera ono w sobie intuicję, dzięki której możliwe jest prawdziwe, choć niejasne i niekonceptualne, poznanie otaczającej nas rzeczywistości oraz świadmość przynależności do niej. $\mathrm{Z}$ tego doświadczenia rodzi się religia. Innymi słowy, religia jest - używając jego własnych sformułowań „czuciem i doświadczeniem nieskończoności”; a konkretniej - świadomością własnego ograniczenia i nietrwałości wobec nieskończoności całości, z którą jest się połączonym i od której jest się uzależnionym.

Nie ma w religii poznania Boga, lecz poczucie Jego obecności i posiadanej z Nim relacji, jednak bez możliwości powiedzenia czegokolwiek o tym, jaki On jest. Bóg bowiem ukazuje się nam i objawia tylko w i poprzez uczucie uzależnienia, które jest konstytutywną i ustanawiającą rzeczywistością religii.

Stwierdzenie, że religia wyrasta z poczucia nieskończoności, przyczyniło się do pojawienia się trudności w ukazaniu wyjątkowości chrześcijaństwa na tle innych religii. Zaakcentowanie uczucia doprowadziło także do przypisania drugorzędnego charakteru doktrynie chrześcijaństwa. Dogmaty i instytucje kościelne są jedynie sposobem wyrazu, poprzez który uczucie ewoluuje i rozwija się. Podkreślając jego znaczenie kosztem poznania, Schleiermacher pozostawił teologii protestanckiej (na którą wpłynął w sposób bardzo istotny w XIX wieku) głęboko dwuznaczną spuściznę.

\section{Specjalizacje teologii i metoda dydaktyczna}

Średniowieczne sumy teologiczne zawierały - przynajmniej w założeniu - wykład całej wiedzy teologicznej. Synteza teologii nie wykluczała jednak mniej lub bardziej świadomego odwoływania się do różnych metod, bowiem nie wszystkie kwestie można traktować w ten sam sposób. Z owego jednolitego pnia, jakim były summae, poczęły się odrywać kolejne dziedziny, przekształcając się w poszczególne dyscypliny teologiczne. Proces ten osiagga swoją kulminację w XVIII wieku. I tak z perspektywy akademickiej $\mathrm{z}$ teologii zostaje wydzielony podstawowy trzon - teologia dogmatyczna - 
i cztery gałęzie lub dyscypliny, które posiadają metodologiczną autonomię: teologia fundamentalna, teologia moralna, teologia pastoralna $\mathrm{i}$ - pozostająca jeszcze wówczas na marginesie struktur uniwersyteckich - teologia duchowości.

Aby uzupełnić obraz teologii w XVIII wieku, trzeba wskazać na fakt, że obok krystalizacji specjalności teologicznych, miał miejsce inny proces: upowszechnienie traktatów jako metody wykładu teologicznego.

Powstała w średniowieczu metodologia nauczania, oparta na komentarzu Sentencji Piotra Lombarda - utrzymała się przez pierwszy okres epoki nowożytnej, choć z czasem Sentencje zostały w znacznej mierze zastąpione Sumq teologiczna Tomasza z Akwinu. Od drugiej połowy XVII wieku, w konsekwencji złożonego zespołu czynników - od zamiłowania do systemu wprowadzonego przez myśl racjonalistyczną, po pragnienie wykorzystania w formacji seminaryjno-kapłańskiej tekstów, które swą strukturą zbliżałyby się do Katechizmu ogłoszonego po Soborze Trydenckim - metoda komentowania mistrzów traciła swoją popularność wskutek rozpowszechnienia się podręczników czy traktatów o charakterze systematycznym, analogicznych do tych, które dotrwały do naszych dni. W połowie XVIII wieku czas komentatorów dobiegł końca, a zwycięstwo podręczników można uważać za całkowite, co da się sprawdzić podczas przeglądania listy dzieł opublikowanych przez profesorów na wydziałach czy w seminariach w ciagu tego stulecia.

To przejście od komentarzy do podręczników oznaczało w rzeczywistości coś ważniejszego niż zwykłą zmianę struktury w porządku czy podziale materiału: w rzeczywistości przyniosło ze sobą modyfikację metodologii nauczania, a zatem całej formacji. Metoda średniowieczna - i, przynajmniej w pewnym stopniu, metoda późniejszych, naśladujących ją komentatorów - opierała się na quaestio, analizie jakiejś kwestii czy problemu postawionego przez mistrza, który wraz z uczniami starał się go rozwiązać. Natomiast metoda podręcznikowa dąży do uporządkowanego wykładu doktryny, prowadzonego przez mistrza, i wykorzystuje przy tym porządek lub schemat, w którym każdy punkt zajmuje odpowiednie dla siebie miejsce, oraz przedstawia w każdym rozdziale prawdę lub tezę, uzasadnianą poprzez odniesienie do uzasadniających ją argumentów. Mówiąc krótko: ordo inventionis, właściwa quaestio, zostały zastapione przez ordo expositionis, wraz z korzyściami - przekazywaniem całości informacji, skończonym wykładem ale i z ograniczeniami - słabszym naciskiem na kreatywność umysłową które taka zmiana zakłada ${ }^{47}$.

${ }^{47}$ Por. J. L. Illanes, J. I. SARANYANA, Historia teologii, dz. cyt., s. 328-329. 
Teologia podręcznikowa miała charakter polemiczny, wymierzony przeciwko reformatorom. Skupiona na kwestiach doktrynalnych, nie odnosiła się do codzienności, w której żyli świeccy. Jednocześnie zaznaczał się w niej coraz bardziej wpływ Magisterium Kościoła. Wybór jego dokumentów soborowych, papieskich i biskupich, dokonany przez Denzingera i opublikowany po raz pierwszy w 1854 roku, stał się swoistą „nową księgą sentencji”.

\section{F. Współczesność - teologia historyczno- -hermeneutyczna}

Pod koniec XIX wieku, w wielu kręgach intelektualnych dostrzeżono to, co D. Bonhoeffer określi później jako ruch świata ku swej autonomii. Ludzie odkryli prawa rządzące światem, a także reguły, które kierują kulturą, religią, sztuką i polityką. Świat utwierdził się w przekonaniu, że opierając się na tych zasadach, funkcjonuje bez Boga równie dobrze jak wcześniej z Nim. W Kościele interpretowano to krzepnięcie we własnej autonomii jako odchodzenie od Boga i podejmowano próby przeciwstawienia się temu procesowi. Jednakże im bardziej eksponowano wiarę przeciwko niemu, tym bardziej świat pojmował siebie w kategoriach nie-chrześcijańskich.

\section{W stronę podmiotowości}

Poczuciu autonomii towarzyszył antropocentryzm, przynoszacy odmienne spojrzenie na ludzkie poznanie. Wpływ filozofii Kanta, który uznał centralną, twórczą rolę podmiotu w konstytuowaniu świata, był znaczący. $\mathrm{W}$ takiej perspektywie istnienie świata pokrywało się z granicami ludzkiego rozumu.

Wspomniana autonomia i antropocentryzm rzutowały na rozwiązania w koncepcjach teologicznych, nieortodoksyjnych z punktu widzenia katolicyzmu, uwarunkowanych protestanckim rodowodem ich autorów. Prawdy religijne zredukowano do poruszeń świadomości lub uczucia. Natomiast wartość samej religii pochodziła z rozumowej krytyki jej zasad. Dopiero taka zracjonalizowana pobożność kształtowała człowieka jako osobę: ludzkie życie miało być doskonalone nie przez formalizm doktryn i przykazań, ale przez osobisty wysiłek wypływający z rzetelnego namysłu. W centrum religii stanął człowiek, jego możliwości i ograniczenia, a nie prawdy objawione przez Boga. 
Od połowy XIX wieku dynamicznie i gruntownie rozwijała się w kręgach protestanckich biblijna krytyka historyczno-literacka. Znajomość języków wschodnich, osiągnięcia archeologii, metody historii i literatury zostały wprzęgnięte w odczytanie tekstu Pisma Świętego. Twórcy teologii protestanckiej doszli do wniosku, że nie da się sformułować idealnej doktryny chrześcijańskiej, nie ma bowiem idealnej formy teologicznej, ponieważ ta podlegała i podlegać będzie wszelkim ograniczeniom, jakie niesie ze sobą historia.

A. von Harnack (1851-1930) w swej Historii dogmatów dokonał rozróżnienia pomiędzy „Ewangelią” i „Ewangelią w historii”. Uważał, że historyk powinien uchronić Kościoły przed podwójną iluzją, która polega na „pojmowaniu dogmatu jako czystego wykładu Ewangelii” i na myśleniu, ,że dogmat zawsze był taki sam w ich łonie i że w konsekwencji zawsze ograniczano się do jego wyjaśniania, a teologia kościelna nigdy nie miała innego zadania, jak rozwijanie zawsze tożsamego dogmatu i odpieranie przychodzących z zewnątrz herezji" ${ }^{48}$.

Harnack miał jednak nadzieję, że „oddzielenie” Ewangelii i formy dogmatycznej, jaką przyjęła w ramach pewnej koncepcji świata, „oddzielenie” jądra i skorupy, pozwoli zachować elementy „ponadczasowe”. Owymi elementami „ponadczasowymi” Ewangelii są: Królestwo Boże i jego nadejście, Bóg Ojciec i nieskończona wartość duszy ludzkiej, najwyższa sprawiedliwość i przykazanie miłości.

Centralna teza Harnacka była następująca: „Badanie historii dowodzi, że chrześcijaństwo dogmatyczne, że dogmaty w ich koncepcji i strukturze, są dziełem ducha greckiego na polu Ewangelii" "49. Owa hellenizacja jest nade wszystko dziełem teologów - zwłaszcza greckich apologetów i Orygenesa. Luter usiłował dokonać rewizji tego procesu. To on „na nowo postawił światło Ewangelii na świeczniku i podporządkował mu dogmat”.

\section{Tendencja absolutyzacji doktryny}

Tymczasem teologia katolicka podążała w zupełnie innym kierunku. U schyłku XIX wieku przeżyła coś, co można nazwać „kanonizacją” tomizmu. Przyczyniła się do tego m. in. encyklika Leona XIII Aeterni Patris na

${ }^{48}$ Cyt. za: CH. Theobald, Faza trzecia. Od I Soboru Watykańskiego do lat pięćdziesiqtych: objawienie, wiara i rozum, natchnienie, dogmat i nieomylność magisterium, [w:] B. Sesboüe, Ch. Theobald (red.), Historia dogmatów, t. IV: Słowo zbawienia. Doktryna Stowa Bożego. Usprawiedliwienie i dyskurs wiary. Objawienie i akt wiary. Tradycja, Pismo Święte i magisterium, Kraków 2003, s. 328.

${ }^{49}$ Tamże, s. 330. 
temat filozofii chrześcijańskiej. Po długim rozwinięciu papieża na temat epoki Ojców, którzy „przyjęli to, co u dawnych filozofów wydawało im się zgodne z prawdą i mądrością i którzy (...) odrzucili to, czego nie mogli poprawić”, pojawia się w dokumencie drugie rozwinięcie o „doktorach Średniowiecza, znanych pod mianem «scholastyków»”, którzy „pieczołowicie zbierają (...) bogate i obfite żniwo doktryny, rozsiane tu i ówdzie w niezliczonych działach Ojców i czynią zeń jakby jeden skarb, dla użytku i wygody przyszłych pokoleń" 50 .

W tym właśnie miejscu Leon XIII wypowiada swą słynną pochwałę „św. Tomasza, który (...) w pewien sposób odziedziczył inteligencję wszystkich (...). Tomasz zebrał ich nauki, niczym rozproszone członki tego samego ciała; zgromadził je, ułożył w godnym podziwu porządku i tak bardzo wzbogacił, iż uważa się go za szczególnego obrońcę honoru Kościoła"51.

Doktor, który „odziedziczył inteligencję wszystkich”, umieszczony został przez Leona XIII, z powodu realizmu myśli i z racji zdolności do odrzucania przeciwnych błędów, w pozycji niemal „trans-historycznej”: „wielki Doktor doszedł do owego podwójnego skutku, jakim jest samodzielne oddalenie wszystkich błędów z wcześniejszych epok i dostarczenie niezwyciężonego oręża dla rozpoznania tych, które bez wątpienia pojawią się w przyszłości”, ${ }^{2}$.

Pomimo tej tendencji do absolutyzowania istniejącej doktryny teologicznej, w obrębie katolicyzmu pojawiły się wysiłki głoszenia treści wiary ludziom owego czasu w sposób adekwatny. Chodziło o unowocześnienie chrześcijaństwa, uczynienie go spójnym z nowożytnym poglądem na świat. $\mathrm{Z}$ czasem wysiłki te określi się mianem modernizmu, jakkolwiek trudno zamknąć go w jednolity system. Rozwijał się on w obszarze zakreślonym przez trzy postawy. Pierwszą z nich - nieprzejednaną - reprezentowali zasadniczo neoscholastycy, którzy nie akceptowali jakiejkolwiek adaptacji czy zmiany. Postawę drugą przyjmowali ci, którzy uznawali konieczność zmian, ale nie za wszelką cenę, krytycznie odróżniając przemiany dobre od złych (M. Blondel, M. J. Lagrange, L. Laberthonière i L. Duchesne). Postawa trzecia charakteryzowała tych, którzy w imię nauki i rozumu byli gotowi wyrzec się tradycji Kościoła i jego Magisterium (A. Loisy, E. Le Roy i G. Tyrrel).

Modernistyczne próby odnowy Kościoła spotkały się z reakcjami Magisterium, które bez przesady można określić jako wyraz paniki. Książki modernistów pojawiły się na Indeksie od 1903 roku. W 1907, w dekrecie

\footnotetext{
${ }^{50}$ Cyt. za Ch. Theobald, dz. cyt., 364.

${ }^{51}$ Tamże.

${ }^{52}$ Tamże.
} 
Lamentabilii sane exitu, Święte Officjum potępiło sześćdziesiąt pięć twierdzeń charakterystycznych dla modernizmu biblijnego i teologicznego. W kilka miesięcy później św. Pius X wydał encyklikę Pascendi, zawierającą uproszczone opracowanie systemu modernistycznego, który jako jednolity i koherentny istniał tak naprawdę jedynie w samej encyklice. Dokument sprowadza modernizm jedynie do korzeni „fałszywej filozofii”. Tymczasem jego protagonistami byli nie tylko teologowie i filozofowie, ale przede wszystkim historycy. A zatem grę między dyscyplinami, opartą na trójkącie nauk humanistycznych, filozofii i teologii zredukowano do dwóch biegunów. Zadziwia definicja modernizmu ujmowanego jako ,spotkanie wszystkich herezji”. Wyraża ona apokaliptyczną wizję świata jej autora. Postulat dostosowania się do nowoczesności miałby być zgubą dla Kościoła. Dyscyplinarny skutek encykliki okazał się brzemienny. Integrystyczna reakcja na modernizm osłabiła teologię na wiele lat. Nie na tyle jednak, by wartościowe wpływy modernizmu jej nie przeniknęły i w pewnym sensie nie przemieniły.

\section{Pomiędzy faktem historycznym a jego interpretacją}

Z czasem w obrębie katolicyzmu rozwinęła się interesująca dyskusja wokół koncepcji teologii kerygmatycznej czy teologii przepowiadania, opracowanej przez profesorów z jezuickiego Wydziału Teologicznego w Innsbrucku. Przepowiadanie chrześcijańskie - utrzymywał m.in. Joseph A. Jungmann (1889-1975) - traci w epoce współczesnej na wyrazistości, gdyż nie potrafi przekazać wielkiej nowości, jaką zakłada głoszenie Ewangelii, a jest to w dużej części konsekwencja podporządkowania go teologii o orientacji zdecydowanie intelektualnej, a nawet intelektualistycznej. Stąd propozycja stworzenia dwóch teologii: $\mathrm{z}$ jednej strony teologii naukowej, o orientacji metafizyczno-systematycznej, skoncentrowanej na tajemnicy Boga jako takiej; z drugiej strony - teologii przepowiadania, o charakterze historycznopsychologicznym, zbudowanej wokół postaci Chrystusa i Jego dzieła zbawienia.

Propozycja ta spotkała się z oporem ze strony większości teologów, którzy sądzili, iż rozróżnienie między dwiema teologiami było nieodpowiednie, i ich nie satysfakcjonowało. Rozwiązaniem nie było budowanie dwóch równoległych teologii, lecz raczej odnowienie - także na poziomie wykładu podręcznikowego, przeciw któremu skierowana była znaczna część zarzutów - teologii jako takiej: wymiar zbawczy jest faktycznie współistotny prawdzie objawionej i dlatego winien być obecny w każdym teologicznym przedsięwzięciu. 
Dwubiegunowe napięcie pozostało. $\mathrm{Z}$ jednej strony oddziaływały inspiracje modernistyczne, prowokujące myślenie o historycznym zakotwiczeniu objawienia i teologii. Z drugiej strony, w obrębie ortodoksyjnego katolicyzmu pojęcie „względności” formuł dogmatycznych wzbudzało strach. Jak pisał Chenu - świadek tamtych czasów: „Teologia «oficjalna» uważała formuły, w jakich się wyraża wiara, za niezmienne i odrzucała samo nawet pojęcie ewolucji”. Działo się tak pomimo ważnego wkładu, jaki wnieśli w XIX wieku do myśli katolickiej J. A. Möhler (1796-1838), pisząc o tradycji i J. H. Newman (1801-1890), określając reguły rozwoju dogmatu. Jednocześnie Magisterium Kościoła ukazywało tomizm jako „super-ortodoksję”. Nauczanie teologii sprowadzało się, według Chenu, do powtarzania „prawd abstrakcyjnych i jałowych, tak jakby wiara była przedmiotem posiadania" ${ }^{33}$.

W takiej sytuacji powstało centrum odnowy teologicznej XX wieku dominikańska szkoła Le Saulchoir, w której posłużono się metodą historyczna, jednak przy zachowaniu spekulatywnego sposobu myślenia. Celował w tym M. D. Chenu (1895-1990). Analizował on teologię XII i XIII wieku w celu ukazania, jak kwestie pozornie czysto techniczne są faktycznie związane z umysłowym i kulturowym podłożem, jakim każdy myśliciel się żywi i na jakie reaguje.

Chenu uprawiał teologię w ciagłości ze św. Tomaszem z Akwinu, jednak była to ciagłość raczej formalna niż materialna. Teologia - twierdził winna być solidarna ze swą epoką, a zatem nie może sprowadzać się do ustalonych pojęć i formuł, nawet jeśli chodziłoby o pojęcia lub formuły ukute przez osobę o tak wielkiej potędze intelektualnej jak Akwinata. Ciaggłość w stosunku do Tomasza zakłada więc nie tyle ciagłość pewnej doktryny, ile ciaggłość pewnej postawy i ducha: urzeczywistnianie w naszych czasach - w związku ze współczesnymi problemami, kulturą, myślą - tego, co Tomasz urzeczywistniał w swoich dziełach.

Chenu ukazał konieczność uwzględniania wymiaru historycznego w teologii. Wszystko, czym teologia może się zajmować, dzieje się w historii. Mówiąc inaczej: historia wyznacza właściwy zakres poruszania się, uwalnia od abstrakcji i sprowadza ją do wymiarów egzystencjalnych człowieka. Francuski teolog zwrócił uwagę na fakt, że tworząc system, mamy już swoje pomysły na to, jaki Pan Bóg jest, jakieś aprioryczne założenia, i Jego Objawienie traktujemy jedynie jako pewne przesłanki, coś, czym próbujemy uzasadnić czy też wzmocnić nasz system. Uwzględniając wymiar historyczny, teologia przestaje być jedynie systemem, sztuką dla sztuki. Uka-

53 J. DuQuesne, O wolności poszukiwań teologicznych. Rozmowy z o. M. D. Chenu, Warszawa 1977, s. 34. 
zuje znaczenie Boga dla człowieka w wymiarze dziejów świata, Kościoła i osobistego życia. W gruncie rzeczy, odkąd człowiek został stworzony, jest tylko jedna historia - historia zbawienia; i tylko niektórym się wydaje, że istnieje również historia świecka, niepowiązana $\mathrm{z}$ historią zbawienia ${ }^{54}$.

Zaakcentowaniu wymiaru historycznego teologii towarzyszyły inne tendencje odnowy rozwijane nie tylko przez dominikanów w Le Saulchoir niedaleko Paryża (obok M. D. Chenu, A. Gardeil, Y. Congar), ale również przez jezuitów w Fourvière pod Lyonem (H. de Lubac i J. Daniélou) i wybitnych myślicieli niemieckich (E. Przywara, R. Guardini, O. Casel) ${ }^{55}$.

Najpierw wyeksponować należy zainteresowanie Bibliq i zastosowanie metody historyczno-krytycznej, co obficie zaowocowało poszukiwaniem egzegezy, która łącząc metody filologiczne i historyczne, umieściłaby je w kontekście zdecydowanie teologicznym.

Z kolei studia patrystyczne uświadomiły teologom, że teksty Ojców Kościoła nie mogą pozostawać prostymi punktami odniesienia lub zwykłym uzupełnieniem argumentacji powstałej na ich marginesie, lecz winny być podstawowymi źródłami ukierunkowania i inspiracji.

Odnowa liturgiczna przyniosła nie tylko ożywienie wiary, lecz również pewne poczucie tajemnicy - rzeczywistej łączności z Bogiem - i świadomość jednolitego, organicznego charakteru wspólnoty Kościoła:

„Jeśli przyjrzymy się tej sprawie dokładniej - pisze Guardini (1885-1968) to zrozumiemy, że liturgia nie jest niczym innym, jak tylko szczególną formą naszego bezpośredniego stosunku do Zbawiciela, który był historycznie i który jest obecny poza wszelką historią. Formą szczególną dlatego, że nie jest zakorzeniona $\mathrm{w}$ jednostce, lecz $\mathrm{w}$ zbiorowości (...). W liturgii cała wspólnota wiernych, a tym samym każdy jej członek, wchodzi w ową bezpośrednią styczność ze Zbawicielem, przy czym jest to w swojej istocie akt kontemplacyjny: akt medytacji, modlitwy, udziału w świętej Ofierze i w Sakramentach" ${ }^{, 56}$.

Utrwaliło się przekonanie, że wiara katolicka ma w swym centrum nie jakąś ideę, lecz rzeczywistość Chrystusa żywego i obecnego w Kościele. Przyczyniło się to do upowszechnienia teologii o mocnych akcentach egzy-

${ }^{54}$ M. D. CHENU, Lud Boży w świecie, Kraków 1968, s. 50-51.

${ }^{55}$ Por. G. ThILs, Orientations de la théologie, Louvain 1958, s. 57-66; E. VILANOVA, Historia de la teología, t. III, Siglos XVIII, XIX, XX, Barcelona 1992, s. 873-898; R. VANDER Gucht, H. Vorgrimler (red.), Bilan de la théologie du XX siècle, t. 2, Tournai 1971; R. WINLING, Teologia wspótczesna 1945-1980, Kraków 1990; G. LAFONT, Histoire théologique de l'Église catholique. Itinéraire et forme de la théologie, Paris 1994, s. 349-384.

${ }^{56}$ R. GuardinI, Misterium liturgii, [w:] Bóg daleki i bliski, Poznań 1991, s. 151. 
stencjalnych, innymi słowy teologii - jak to zaznaczał m. in. J. Daniélou (1905-1974) - adresowanej do człowieka, a nie rozwijanej teoretycznie:

„Słowo jest słowem zbawienia (Dz 13, 26), słowem krzyża (1 Kor 1, 18), słowem pojednania $(2$ Kor 5,19$)$. Treścią słowa nie jest doktryna, ani mądrość, jak w nauczaniu filozofów czy mędrców. Jest ono głoszeniem jedynego zdarzenia, zdarzenia Wielkanocy. Treścią słowa jest tylko męka i zmartwychwstanie Chrystusa, rozpatrywane jako decydujący fakt historyczny, dzieło boskie o zasięgu kosmicznym wstrząsające światem. Polega ono na zwiastowaniu niepojętych bogactw Chrystusowych (Ef 3, 4), przez które została otwarta era łaski. Oto treść Ewangelii, która ma być głoszona" ${ }^{, 5}$.

Przezwyciężona została teologia „dogmatyzująca”, tzn. refleksja prezentująca prawdy wiary przede wszystkim w oparciu o Pismo Święte a jeszcze bardziej - o Magisterium Kościoła. Jej troskę stanowił skrupulatny przekaz doktryny. Brakowało jej jednak wrażliwości historycznej, czego następstwem było identyfikowanie prawdy objawionej z aktualnym sposobem jej przekazywania. Co więcej, taka teologia sprawiała wrażenie, jakby jej zasadniczą troską było budowanie zwartego systemu, a nie jej adresat - człowiek z jego aktualnymi problemami.

$\mathrm{W}$ miejsce teologii dogmatyzującej pojawiła się, zarówno w środowisku katolickim jak i protestanckim, teologia bardziej „hermeneutyczna”, starająca się uwypuklić związek pomiędzy przeszłością - z jej tekstami i formułami wiary - a teraźniejszością. Poznanie odziedziczone z przeszłości jest nierozdzielnie związane $\mathrm{z}$ jego interpretacją i aktualizacją. Teologia hermeneutyczna nie zadawala się przekazywaniem niezmiennych dogmatów wiary katolickiej, lecz chce ukazać aktualne znaczenie Słowa Bożego. Takie podejście wiąże się z uznaniem antropocentryzmu panującego w nowożytnym myśleniu filozoficznym. Refleksja teologiczna nie tylko stara się być wrażliwa na wyzwania człowieka, ale również często zaczyna się od niego, a nie od danych Objawienia. Bez wattpienia najwybitniejszym reprezentantem takiego nurtu teologii współczesnej jest Karl Rahner (1904-1984).

Zapoczątkowany w epoce nowożytnej dualizm teologii oscylującej pomiędzy subiektywizmem teologii protestanckiej a absolutyzacją historycznej, opracowanej już doktryny został, jak się wydaje, przezwyciężony. Teologia hermeneutyczna połączyła dążenie do uwypuklenia znaczenia Objawienia dla człowieka konkretnego czasu z umiejętnością postrzegania ograniczoności każdego kształtu, sytemu wiary, wynikającego z jego uwikłania w historii.

${ }^{57}$ J. DANiélou, Bóg i my. W stronę Chrystusa, Kraków 1965, s. 296 n. 
Uwzględniając różne typy teologii chrześcijańskiej, jakie rozwijały się na przestrzeni wieków, można stwierdzić, że rozwój dokonywał się w trzech zasadniczych wymiarach. W ciagu historii uwzględniano je bardzo różnie, jednak zachowanie harmonii pomiędzy nimi stanowi, jak się wydaje, niezbędny warunek jej pomyślnego rozwoju.

Najpierw trzeba wyeksponować wymiar duchowy teologii. Rodzi się ona ze spotkania z Jezusem Chrystusem. Jej pierwotnym korzeniem jest wiara, bezpośrednia więź wierzącego z Bogiem. To on jest inicjatorem każdej teologii. Świadczy o tym Nowy Testament. O konieczności żywego kontaktu teologa z Bogiem pisali Orygenes, Augustyn, Anzelm, a później jeszcze Bernard z Clairvaux. Przezwyciężenie odziedziczonego po poprzednich wiekach zerwania między teologią a duchowością stanowi najbardziej znaczący zwrot w refleksji nad teologią katolicką XX wieku.

Drugi wymiar wyrósł już w okresie inicjacji teologii, kiedy to uzmysłowiono sobie konieczność prowadzenia dialogu ze światem, a bardziej precyzyjnie: dialogu wiary z filozofia. To właśnie ona pobudzała do pogłębionej refleksji nad Objawieniem, jak to czynił Justyn. Filozofia dostarczała precyzyjnych narzędzi, by tę refleksję wyrazić, co podkreślał Klemens Aleksandryjski. Ta systematyczna refleksja doprowadziła do pierwszych syntez teologii (Orygenes i Augustyn), które pod względem rozmiarów osiagnęły swoje apogeum w okresie złotego wieku scholastyki (Tomasz z Akwinu). Przesadne akcentowanie wymiaru naukowego prowadziło jednak do poważnych niebezpieczeństw, co w sposób najbardziej wyraźny ujawniło się u schyłku scholastyki. Czysty intelektualizm, uprawianie teologii dla niej samej, doprowadziło do jej wyobcowania, zerwania relacji z człowiekiem.

Połączenie wymiaru naukowego i duchowego teologii nie jest jeszcze jej idealnym modelem. Musi być uwzględniony jeszcze jeden wymiar eklezjalny. Świadczą o tym tendencje zaistniałe już w II wieku. Systemy gnostyckie łączyły bowiem intelekt z mistyka, a stały się jedną z najniebezpieczniejszych herezji chrześcijaństwa. Stało się tak dlatego, że teologię chciano uprawiać bez uwzględnienia jej odniesienia do Kościoła. Już św. Ireneusz wykazywał, że Kościół stanowi kryterium hermeneutyczne teologii. Oznacza to m. in., że chrześcijańska twórczość teologiczna ma być procesem wspólnotowym, który integruje pracę rozlicznych studiów. Jednym z podstawowych faktorów odnowy teologii XIX w Tybindze i w Solesmes oraz w XX wieku w Le Saulchoir i w Fourvière było właśnie siegnięcie po 
wielkie dziedzictwo teologów minionych epok, zwłaszcza po twórczość Ojców Kościoła. 


\begin{tabular}{|c|c|c|c|c|c|}
\hline 要 & 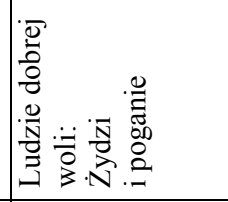 & 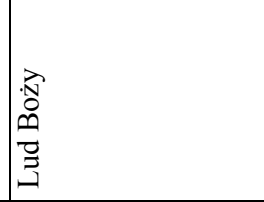 & & 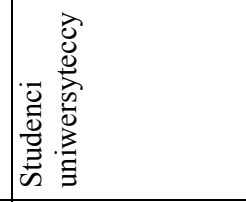 & 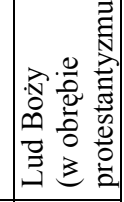 \\
\hline 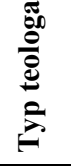 & 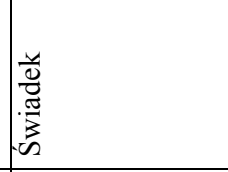 & 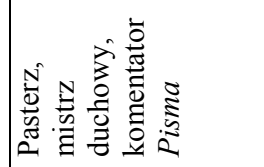 & & 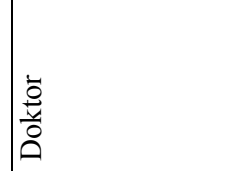 & 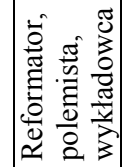 \\
\hline 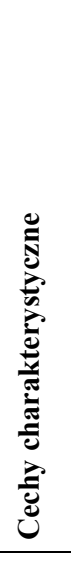 & 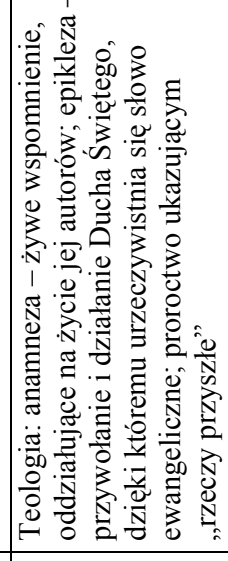 & 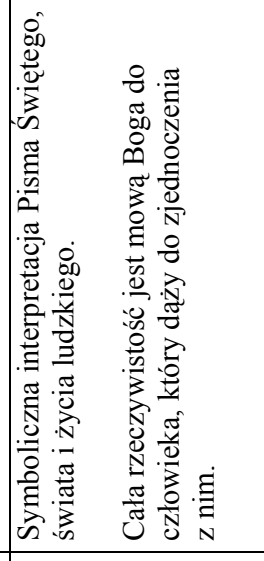 & 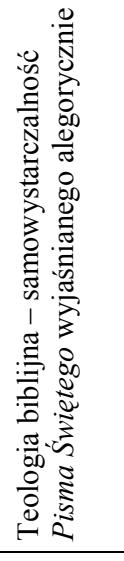 & 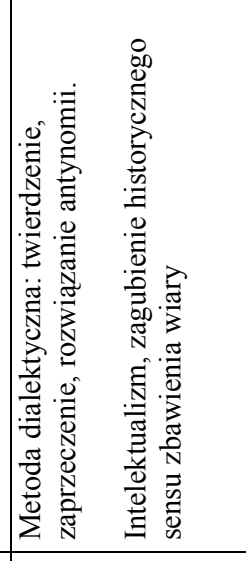 & 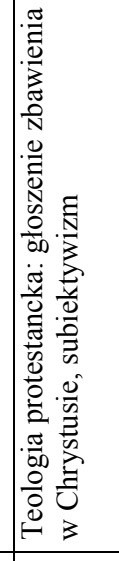 \\
\hline 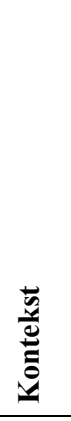 & 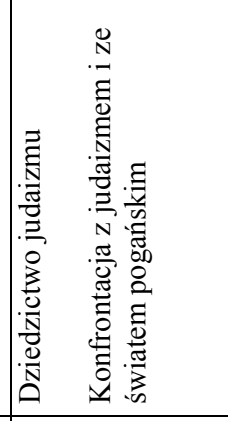 & 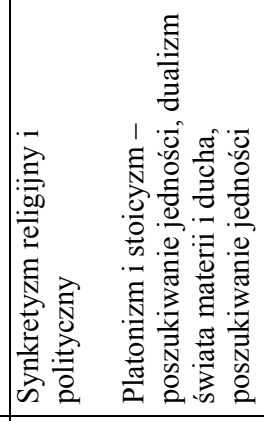 & 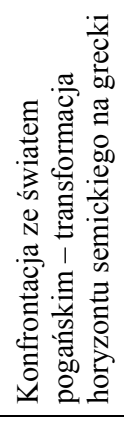 & 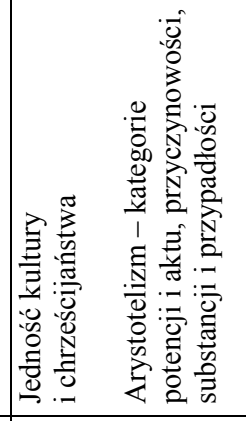 & 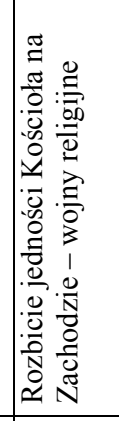 \\
\hline 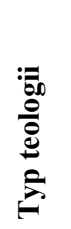 & 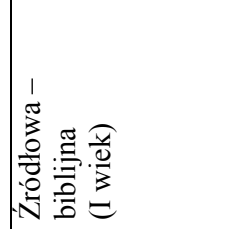 & 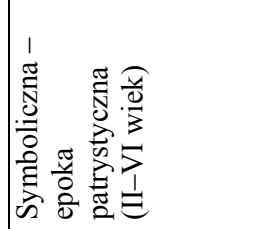 & & 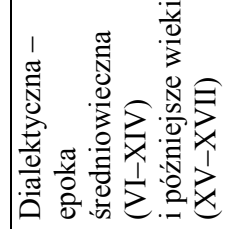 & 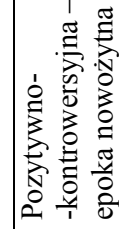 \\
\hline
\end{tabular}




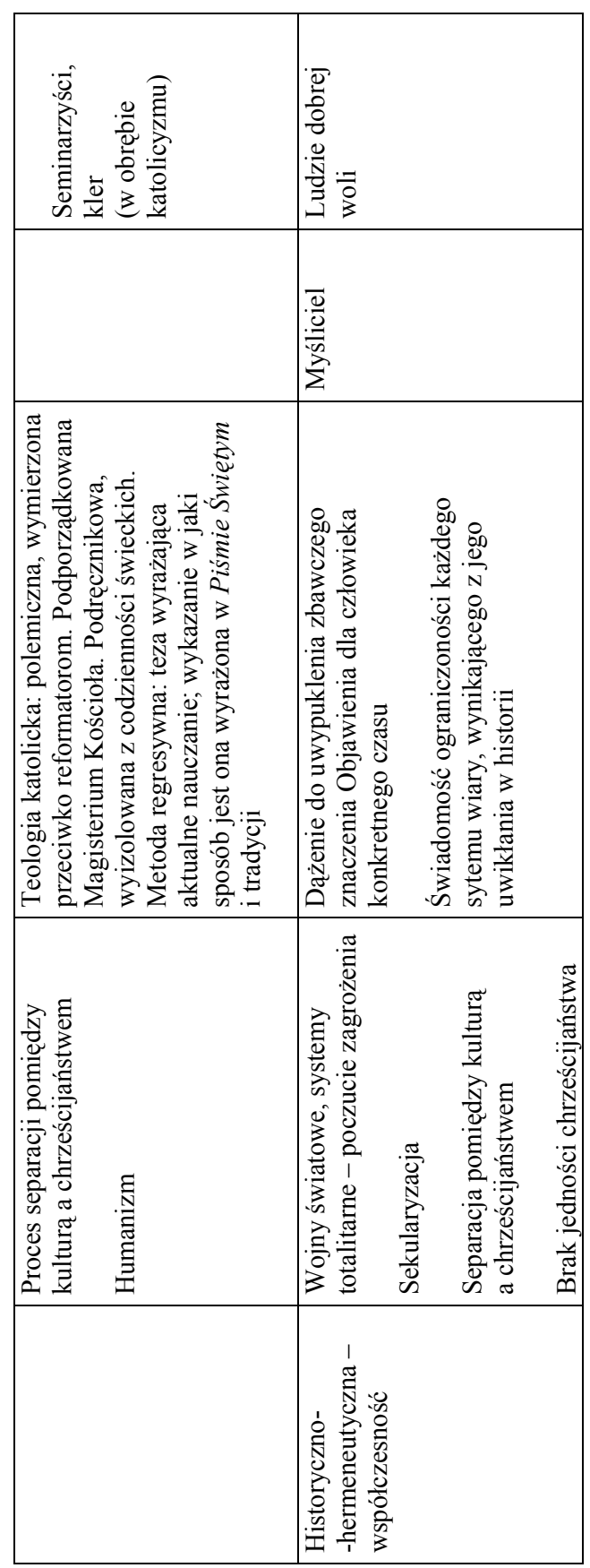

